\title{
Article \\ Role of Sphingosine 1-Phosphate Signalling Axis in Muscle Atrophy Induced by TNF $\alpha$ in C2C12 Myotubes
}

\author{
Caterina Bernacchioni ${ }^{1, *} \mathbb{D}$, Veronica Ghini ${ }^{2,3}$, Roberta Squecco ${ }^{4}$, Eglantina Idrizaj $\left.{ }^{4} \mathbb{(}\right)$, Rachele Garella ${ }^{4}$, \\ Elisa Puliti ${ }^{1}$, Francesca Cencetti ${ }^{1, *}$, Paola Bruni ${ }^{1}$ and Chiara Donati ${ }^{1} \mathbb{C}$
}

1 Department of Experimental and Clinical Biomedical Sciences "M. Serio", University of Florence, 50134 Florence, Italy; elisa.puliti@unifi.it (E.P.); paola.bruni@unifi.it (P.B.); chiara.donati@unifi.it (C.D.)

2 Magnetic Resonance Center (CERM), University of Florence, 50019 Sesto Fiorentino, Italy; ghini@cerm.unifi.it

3 Consorzio Interuniversitario Risonanze Magnetiche di Metallo Proteine (CIRMMP), 50019 Sesto Fiorentino, Italy

4 Department of Experimental and Clinical Medicine, Section of Physiological Sciences, University of Florence, 50134 Florence, Italy; roberta.squecco@unifi.it (R.S.); eglantina.idrizaj@unifi.it (E.I.); rachele.garella@unifi.it (R.G.)

* Correspondence: caterina.bernacchioni@unifi.it (C.B.); francesca.cencetti@unifi.it (F.C.); Tel.: +39-0552751230 (C.B.); +39-0552751243 (F.C.)

Citation: Bernacchioni, C.; Ghini, V.; Squecco, R.; Idrizaj, E.; Garella, R.;

Puliti, E.; Cencetti, F.; Bruni, P.;

Donati, C. Role of Sphingosine 1-Phosphate Signalling Axis in Muscle Atrophy Induced by TNF $\alpha$ in C2C12 Myotubes. Int. J. Mol. Sci. 2021, 22, 1280. https://doi.org/ $10.3390 /$ ijms 22031280

Academic Editor: Daniel Taillandier Received: 24 December 2020

Accepted: 25 January 2021

Published: 28 January 2021

Publisher's Note: MDPI stays neutral with regard to jurisdictional claims in published maps and institutional affiliations.

Copyright: (c) 2021 by the authors. Licensee MDPI, Basel, Switzerland. This article is an open access article distributed under the terms and conditions of the Creative Commons Attribution (CC BY) license (https:/ / creativecommons.org/licenses/by/ $4.0 /)$.

\begin{abstract}
Skeletal muscle atrophy is characterized by a decrease in muscle mass causing reduced agility, increased fatigability and higher risk of bone fractures. Inflammatory cytokines, such as tumor necrosis factor-alpha $(\mathrm{TNF} \alpha)$, are strong inducers of skeletal muscle atrophy. The bioactive sphingolipid sphingosine 1-phoshate (S1P) plays an important role in skeletal muscle biology. S1P, generated by the phosphorylation of sphingosine catalyzed by sphingosine kinase (SK1/2), exerts most of its actions through its specific receptors, $\mathrm{S} \mathrm{P}_{1-5}$. Here, we provide experimental evidence that $\mathrm{TNF} \alpha$ induces atrophy and autophagy in skeletal muscle $\mathrm{C} 2 \mathrm{C} 12$ myotubes, modulating the expression of specific markers and both active and passive membrane electrophysiological properties. NMRmetabolomics provided a clear picture of the deep remodelling of skeletal muscle fibre metabolism induced by $\mathrm{TNF} \alpha$ challenge. The cytokine is responsible for the modulation of S1P signalling axis, upregulating mRNA levels of $\mathrm{S}_{2} \mathrm{P}_{2}$ and $\mathrm{S}_{\mathrm{P}} \mathrm{P}_{3}$ and downregulating those of SK2. TNF $\alpha$ increases the phosphorylated form of SK1, readout of its activation. Interestingly, pharmacological inhibition of SK1 and specific antagonism of $\mathrm{S}_{3} \mathrm{P}_{3}$ prevented the increase in autophagy markers and the changes in the electrophysiological properties of $\mathrm{C} 2 \mathrm{C} 12$ myotubes without affecting metabolic remodelling induced by the cytokine, highlighting the involvement of S1P signalling axis on TNF $\alpha$-induced atrophy in skeletal muscle.
\end{abstract}

Keywords: sphingosine 1-phosphate; skeletal muscle atrophy; tumor necrosis factor alpha; sphingosine 1-phosphate receptors; NMR metabolomics; electrophysiological properties; autophagy

\section{Introduction}

Skeletal muscle atrophy is characterized by a decrease in muscle mass and fiber size as a result of different conditions such as aging, bed rest, cancer, denervation and motor neuron disease [1]. Skeletal muscle atrophy causes reduced agility, increased fatigability and higher risk of bone fractures, thus representing a major burden for health systems, lowering response to treatments and decreasing life expectancy. Although the knowledge on muscle wasting has been advanced during the last 10 years, the dissection of the molecular signalling pathways regulating skeletal muscle atrophy will pave the way for innovative interventions for the discovery of drugs to prevent this pathological condition, which are crucially relevant for neuromuscular diseases, muscle disuse and aging. The regulation of muscle mass depends on the balance between protein synthesis and degradation: during muscle atrophy, the main degradation pathways of the cell are activated. Inflammation 
potently induces muscle wasting and cachexia. Inflammatory cytokines, tumor necrosis factor (TNF) $\alpha$ in particular, are strong inducers of skeletal muscle atrophy. Increased efflux of nitrogen and amino acid from skeletal muscle and loss of body protein have been shown in mice administered with $\mathrm{TNF} \alpha$ [2-5] and in pathological conditions characterized by elevated endogenous TNF $\alpha$ like cancer [6] or experimental sepsis [7]. Li et al. have shown that TNF $\alpha$ is capable of decreasing protein content and activating ATP-dependent proteolysis [8]. The cytokine promotes protein degradation mainly through ROS formation and NFkB activation [9]. Moreover, TNF $\alpha$ plays a crucial role in the metabolic dysregulation related to altered lipid and carbohydrate metabolism that takes place in atrophic conditions driving to increase systemic stress and energy expenditure $[10,11]$.

$\mathrm{TNF} \alpha$, by binding to its specific receptors, activates multiple downstream signalling pathways [12] including the hydrolysis of membrane sphingomyelin, leading to the formation of bioactive sphingolipids such as ceramide and sphingosine [13,14]. The ATPdependent phosphorylation of sphingosine catalyzed by two different isoforms of sphingosine kinase (SK), SK1 and SK2, then generates sphingosine 1-phosphate (S1P). S1P is a pleiotropic molecule that is crucially involved in the regulation of both physiological and pathological processes $[15,16]$. The catabolism of S1P is finely regulated since S1P can be irreversibly cleaved by S1P lyase (SPL) to hexadecenal and phosphoethanolamine or can be reverted back to sphingosine by the action of specific S1P phosphatases (SPP) and non-specific lipid phosphate phosphatases (LPP). The mechanism of action of S1P is dual since it can act as an intracellular messenger and as a ligand of five different specific $\mathrm{G}$ protein-coupled receptors (S1PR), named $\mathrm{S1P}_{1-5}$ [17]. The release in the extracellular environment of S1P is mediated through the specific transporters spinster homolog 2 (Spns2) [18] and Mfsd2b [19] or unspecific transporters belonging to the ATP-binding cassette (ABC) family [20]. S1P signalling plays an important biological role in skeletal muscle [21]. S1P has been shown to be involved in satellite cell activation [22,23] and to improve muscle regeneration in injured $m d x$ mice [24]. In C2C12 myoblasts, S1P acts as negative regulator of cell proliferation and migration and as a powerful activator of myogenic differentiation $[25,26]$. Moreover, the SK/S1P axis in myoblasts appears to be under the control of multiple extracellular cues that exploit this signalling pathway to elicit specific biological responses such as IGF-1 and PDGF $[27,28]$. The sphingolipid significantly reduced the tension decline during fatigue of skeletal muscle [29] and exerted a trophic action in denervated rat soleus muscle [30]. We previously showed that low doses of TNF $\alpha$ promote myogenesis in $\mathrm{C} 2 \mathrm{C} 12$ myoblasts and inhibition of SK and $\mathrm{S}_{1} \mathrm{P}_{2}$ abrogated its pro-myogenic effect [31]. TNF $\alpha$ at high doses induces muscle wasting, essentially by interfering with the ability of satellite cells to differentiate into myofibres [32]. The biosynthesis of ceramide induced by $\mathrm{TNF} \alpha$ has been shown to be involved in the mechanisms leading to muscle loss associated with pathological states [33]. Here, we provide experimental evidence that $\mathrm{TNF} \alpha$ dose-dependently induces atrophy and autophagy in skeletal muscle $\mathrm{C} 2 \mathrm{C} 12$ myotubes, downregulating the protein level of myosin heavy chain (MHC), upregulating the autophagy marker LC3-II and modulating both active and passive electrophysiological membrane properties. Untargeted ${ }^{1} \mathrm{H}-\mathrm{NMR}$ metabolomics provided a clear picture of the deep remodelling of skeletal muscle fibre metabolism induced by TNF $\alpha$ challenge. S1P signalling and metabolism were modulated by the cytokine, being responsible for the upregulation of $\mathrm{S}_{1} \mathrm{P}_{2} / \mathrm{S}_{1} \mathrm{P}_{3}$ mRNA levels and the downregulation of SK2 transcript. Short time of incubation with the cytokine increases the phosphorylated form of SK1, readout of its activation. Interestingly, pharmacological inhibition of SK1 and specific antagonism of $\mathrm{S}_{3} \mathrm{P}_{3}$ prevented the increase in LC3-II and the changes in the electrophysiological properties of $\mathrm{C} 2 \mathrm{C} 12$ myotubes induced by the cytokine, without affecting the metabolic remodelling, thus highlighting the involvement of S1P signalling axis in TNF $\alpha$-induced atrophy in skeletal muscle. 


\section{Results}

The atrophic effect of TNF $\alpha$ was analysed in $\mathrm{C} 2 \mathrm{C} 12$ myotubes. Treatment with increasing concentrations of the cytokine $(25,50,100 \mathrm{ng} / \mathrm{mL})$ for $24 \mathrm{~h}$ induced muscle protein degradation, as demonstrated by the dose-dependent reduction in the structural protein MHC (Figure 1a). Moreover, TNF $\alpha$ induced autophagic proteolysis since the treatment with the cytokine caused a dose-dependent increase in the lipidated form of LC3, LC3-II, accepted as the gold standard for determining autophagosome formation (Figure 1b).

To evaluate the action of TNF $\alpha$ on myotube functional aspects, membrane phenomena related to the excitability and excitation-contraction coupling were analysed (Figure 1c, Table S1). TNF $\alpha$ treatment caused a statistically significant depolarization of the membrane (i.e., increase in RMP, resting membrane potential) compared to control myotubes. To test the possible effect of TNF $\alpha$ on membrane permeability, membrane resistance, $R_{m}$, was measured. The $R_{m}$ value significantly decreased in TNF $\alpha$-treated myotubes, suggesting a leakier membrane under atrophic challenge. The analysis of cell capacitance $\left(C_{m}\right)$, assumed as index of myotube surface membrane, showed a clear significant decrease in the presence of TNF $\alpha$ compared to control myotubes. Accordingly, to assess if the observed $C_{m}$ decrease was due to a reduction in the T-tubular system, we used a previously published procedure [34]. The ratio between the capacitance associated with the tubular membrane $\mathrm{C}_{\mathrm{T}}$ and the capacitance associated with the surface membrane $\mathrm{C}_{\mathrm{s}}, \mathrm{C}_{\mathrm{T}} / \mathrm{C}_{\mathrm{s}}$, was significantly smaller under TNF $\alpha$ treatment compared to control. Moreover, the effect of TNF $\alpha$ on myotube ion currents (Figure 1d) crucial in the control of the excitability and $\mathrm{Ca}^{2+}$ entry in muscle cells was tested. The $\mathrm{K}^{+}$currents evoked in myotubes normally showed a small amplitude. TNF $\alpha$ caused a large and statistically significant increase in outward current size. Representative traces are depicted in Figure $1 \mathrm{~d}$ for control and TNF $\alpha$ treatment, respectively. Similarly, $\mathrm{Ca}^{2+}$ currents showed a very small amplitude. However, $\mathrm{TNF} \alpha$ did not significantly alter the inward current size.

The metabolic shift induced by TNF $\alpha$ in skeletal muscle was characterized by comparing the extracellular metabolomic profiles (exo-metabolome) of $\mathrm{TNF} \alpha$-treated vs. control myotubes. Exo-metabolome provided steady-state levels of metabolites resulting from the balance between production and consumption of each molecule; unsupervised principal component analysis (PCA) was used to obtain a preliminary overview of the data (Figure 1e). From the PCA score plot (PC1 vs. PC2), a discrimination between the two different conditions tested (TNF $\alpha$-treated vs. control myotubes) was clearly visible, indicating a strong influence of the cytokine on myotube metabolic profiles. In particular, treatment with $100 \mathrm{ng} / \mathrm{mL} \mathrm{TNF} \alpha$ for $24 \mathrm{~h}$ induced a metabolic shift towards aerobic glycolysis, characterized by significantly reduced extracellular glucose levels and increased levels of lactate (Figure 1e). In addition, a marked reduction in the extracellular aminoacid content was observed (Figure S1).

The possible involvement of S1P signalling axis in the atrophic effect of TNF $\alpha$ in skeletal muscle was investigated. To this aim, we first examined whether the cytokine was capable of regulating the expression of enzymes implicated in S1P metabolism in C2C12 myotubes. Real Time PCR data illustrated in Figure 2a show that the treatment with $100 \mathrm{ng} / \mathrm{mL}$ TNF $\alpha$ significantly reduced the mRNA expression of SK2 at $24 \mathrm{~h}$ of treatment while the expression of other enzymes involved in S1P metabolism was unaffected by the treatment with the cytokine for 6 or $24 \mathrm{~h}$. We then investigated whether TNF $\alpha$ was able to regulate the protein content of SK1 and SK2. Western blot analysis of SKs levels showed that $100 \mathrm{ng} / \mathrm{mL} \mathrm{TNF} \alpha$ for $24 \mathrm{~h}$ did not modulate SK1 or SK2 protein levels in myotubes (Figure $2 \mathrm{~b}$ ). Since agonist-induced stimulation of SK1/SK2 activity and translocation to the plasma membrane is mediated by phosphorylation $[35,36]$, Western blot analysis using specific anti-phospho-SK1 as well as anti-phospho-SK2 antibodies was performed in myotube lysates following TNF $\alpha$ treatment. Data reported in Figure 2c showed that cell challenge with $100 \mathrm{ng} / \mathrm{mL}$ TNF $\alpha$ provoked a rapid increase in SK1 phosphorylation, detectable at $10 \mathrm{~min}$ of incubation and persistent after $60 \mathrm{~min}$ of treatment. In contrast, the 
phosphorylation state of SK2 was unaffected by TNF $\alpha$ treatment. Collectively, these data indicate that although TNF $\alpha$ does not alter SK protein expression, it is able to rapidly and persistently activate SK1 in myotubes.

a)

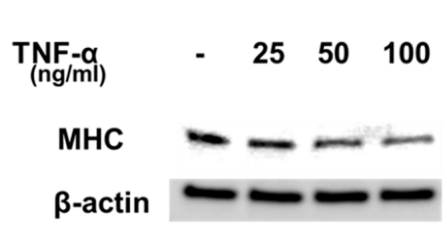

b)

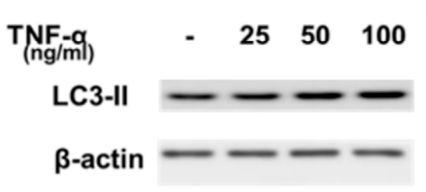

c)
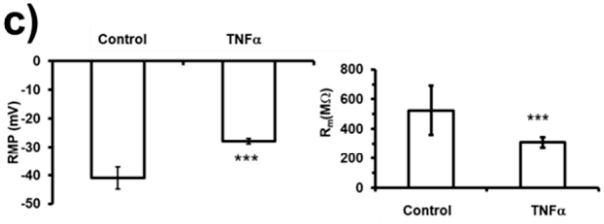

d)
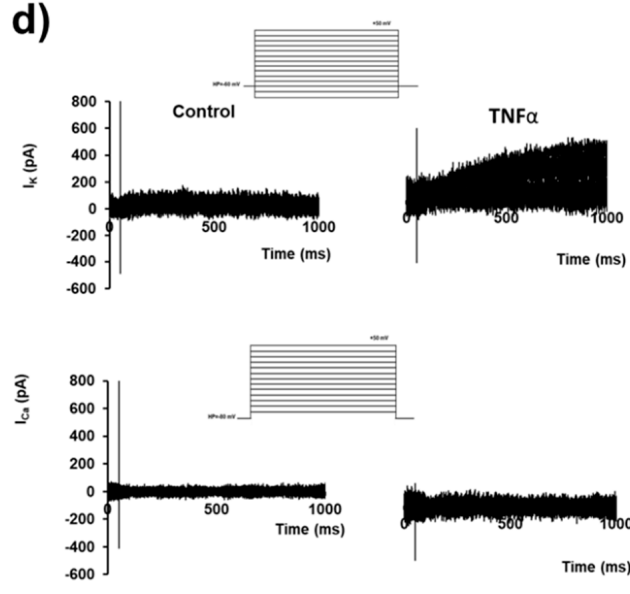

e)
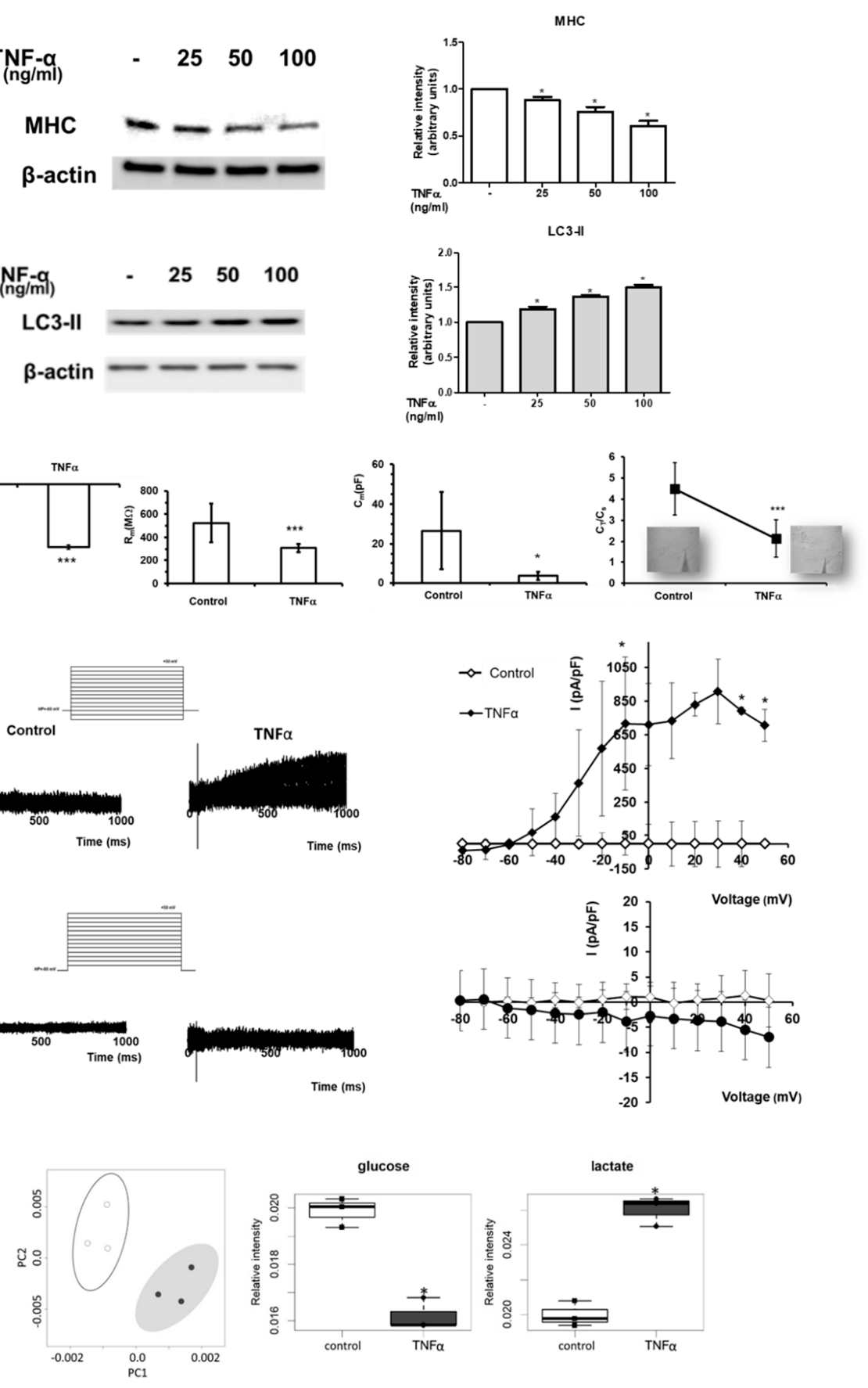

Figure 1. TNF $\alpha$-induced atrophy in $\mathrm{C} 2 \mathrm{C} 12$ myotubes. (a,b) $\mathrm{C} 2 \mathrm{C} 12$ myotubes were treated with $\mathrm{TNF} \alpha$ at the indicated concentrations (25-100 ng/mL) for $24 \mathrm{~h}$. Western blot analysis was performed using specific anti-MHC (a) and anti-LC3 (b) antibodies in cell lysates. Left panels: blot representative of at least three independent experiments with analogous results is shown. Right panels: densitometric analysis of at least three independent experiments. Data are the mean \pm SEM and are reported as protein expression normalized to $\beta$-actin, -fold change over control (set as 1). TNF $\alpha$ decreases the expression of MHC in a statistically significant manner by one-way ANOVA followed by Bonferroni's post hoc test $\left({ }^{*} p<0.05\right.$, treated vs. control). TNF $\alpha$ increases LC3-II in a statistically significant manner by one-way ANOVA followed by Bonferroni's post hoc test $\left({ }^{*} p<0.05\right.$, treated vs. control). (c) Resting membrane potential (RMP) evaluated in current-clamp mode, membrane resistance $\left(R_{m}\right)$ and membrane capacitance $\left(C_{m}\right)$ estimated in voltage-clamp and $C_{T} / C_{s}$ ratio in the different conditions. 
All of the results and number of cells investigated are listed in Table S1 as mean \pm SD. ${ }^{*}$ indicates $p<0.05$ and ${ }^{* * *} p<0.001$ vs. control (unpaired Student's $t$ test). (d) Upper panels: representative outward $\mathrm{K}^{+}$currents (in pA) evoked in response to 1-s long pulse protocol ranging from -80 up to $+50 \mathrm{mV}(\mathrm{HP}=-60 \mathrm{mV})$ in control myotubes and in TNF $\alpha$-treated ones. Overall $\mathrm{I}-\mathrm{V}$ plots related to all the experiments conducted in any conditions are reported. The current amplitude is measured for each voltage step at the end of the pulse. ${ }^{*} p<0.05 \mathrm{vs}$. control (unpaired Student's $t$ test), ( $n=6$ to 7 for the different treatments). Lower panels: typical inward $\mathrm{Ca}^{2+}$ currents (in $\mathrm{pA}$ ) recorded using the solutions described in the Methods section in response to 1-s long pulse protocol from -80 up to $+50 \mathrm{mV}(\mathrm{HP}=-80 \mathrm{mV})$ in control myotubes and in TNF $\alpha$-treated ones. Overall I-V plots related to the amount of experiments conducted in any conditions show not statistically significant differences ( $p>0.05$ vs. control, unpaired Student's $t$ test), ( $n=4$ to 7 , for the different treatments). Data are the mean \pm SD. Error bars are shown when their size is bigger than the symbol. (e) Left panel: metabolomic phenotyping of conditioned media (exo-metabolome) of C2C12 myotubes treated or not with $100 \mathrm{ng} / \mathrm{mL}$ TNF $\alpha$ for $24 \mathrm{~h}$. Score plots of PCA: PC1 vs. PC2. In the score plots, each dot represents a different sample, and each colour represents a different group of samples-white: control; dark grey: TNF $\alpha$. Right panels: boxplot of the metabolites involved in glycolysis. Changes in metabolite levels caused by TNF $\alpha$ were statistically significant by paired Wilcoxon test, $\left({ }^{*} p<0.05\right)$.
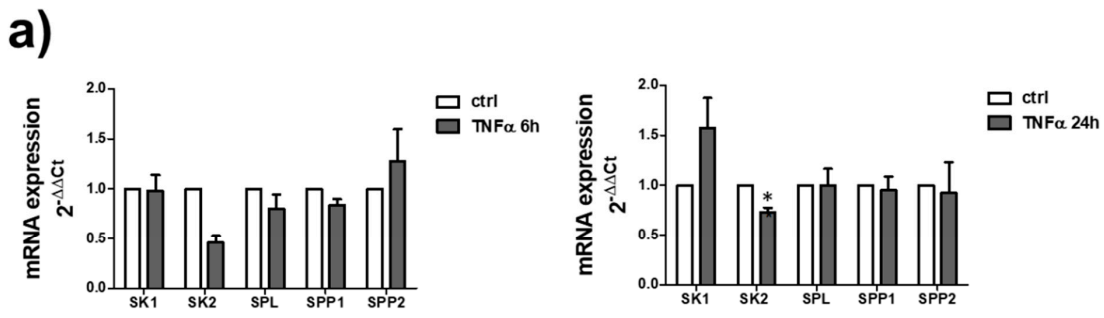

b)
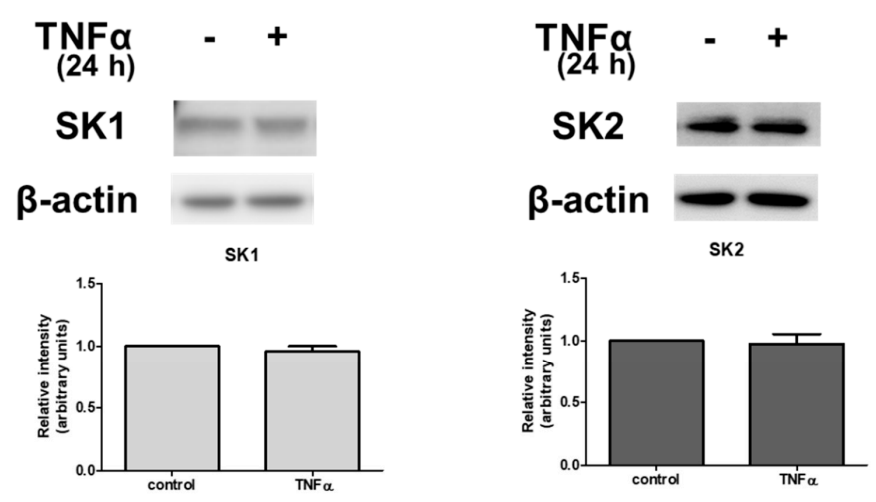

c)
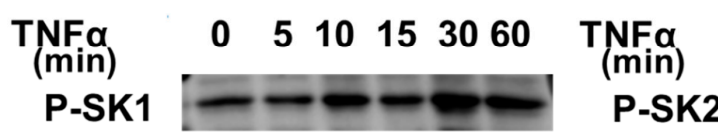

$\begin{array}{llllll}0 & 5 & 10 & 15 & 30 & 60\end{array}$

\section{$\beta$-actin}

\section{$\beta$-actin}
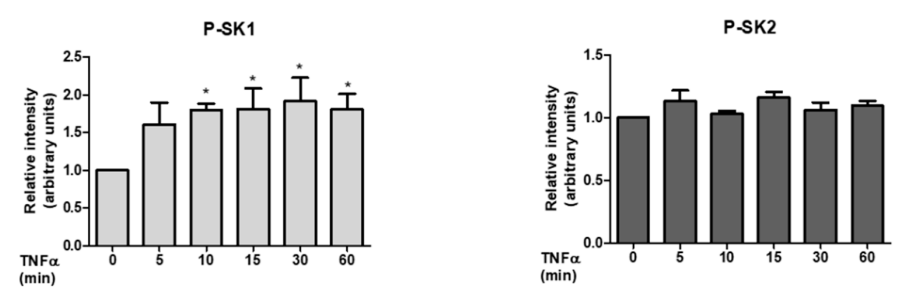

Figure 2. TNF $\alpha$ modulates S1P metabolism. (a) Quantitative mRNA analysis was performed by real-time PCR in total RNA extracted from C2C12 myotubes stimulated or not with $100 \mathrm{ng} / \mathrm{mL} \mathrm{TNF} \alpha$ for the indicated time intervals ( $6 \mathrm{~h}$ and $24 \mathrm{~h})$. mRNA quantitation of S1P metabolism enzymes (SK1, SK2, SPL, SPP1 and SPP2) was based on the $2^{-\Delta \Delta C t}$ method, using 
individual enzyme of the unchallenged specimen as calibrator. Data are the mean \pm SEM of three independent experiments performed in triplicate. The reduction in SK2 expression induced by TNF $\alpha$ was statistically significant by Student's $t$ test $\left({ }^{*} p<0.05\right)$. (b,c) C2C12 myotubes were incubated for the indicated time intervals in the absence or in the presence of $100 \mathrm{ng} / \mathrm{mL} \mathrm{TNF} \alpha$. (b) Top, aliquots of total cell lysates were used to perform Western analysis, using specific anti-SK1 and anti-SK2 antibodies. A representative blot is shown. Bottom, densitometric analysis of at least three independent experiments. Data are the mean \pm SEM and are reported as protein expression normalized to $\beta$-actin, -fold change over control (set as 1). (c) Western blot analysis was performed using specific anti-phospho-SK1 and anti-phospho-SK2 antibodies. A blot representative of at least three independent experiments with analogous results is shown. The histogram represents densitometric analysis of three independent experiments. Data are the mean \pm SEM and are reported as protein expression normalized to $\beta$-actin, -fold change over control (set as 1). The increase in phospho-SK1 content induced by TNF $\alpha$ was found to be statistically significant by one-way ANOVA followed by Bonferroni's post hoc test $\left({ }^{*} p<0.05\right.$, treated vs. control).

The effect of TNF $\alpha$ treatment on S1P signalling was analysed to determine the effect of the cytokine on S1PR expression. The treatment with TNF $\alpha$ deeply modulates S1PR expression pattern in myotubes: quantitative analysis of mRNA demonstrated that the cytokine potently augmented $\mathrm{S}_{2} \mathrm{P}_{2}$ levels (about 2.5 -fold increase at $24 \mathrm{~h}$ of treatment) and $\mathrm{S} \mathrm{P}_{3}$ levels (more than 10-fold increase both at $6 \mathrm{~h}$ and $24 \mathrm{~h}$ of treatment) (Figure 3). In addition, the cytokine significantly reduced the mRNA levels of Spns 2 after $24 \mathrm{~h}$ challenge.
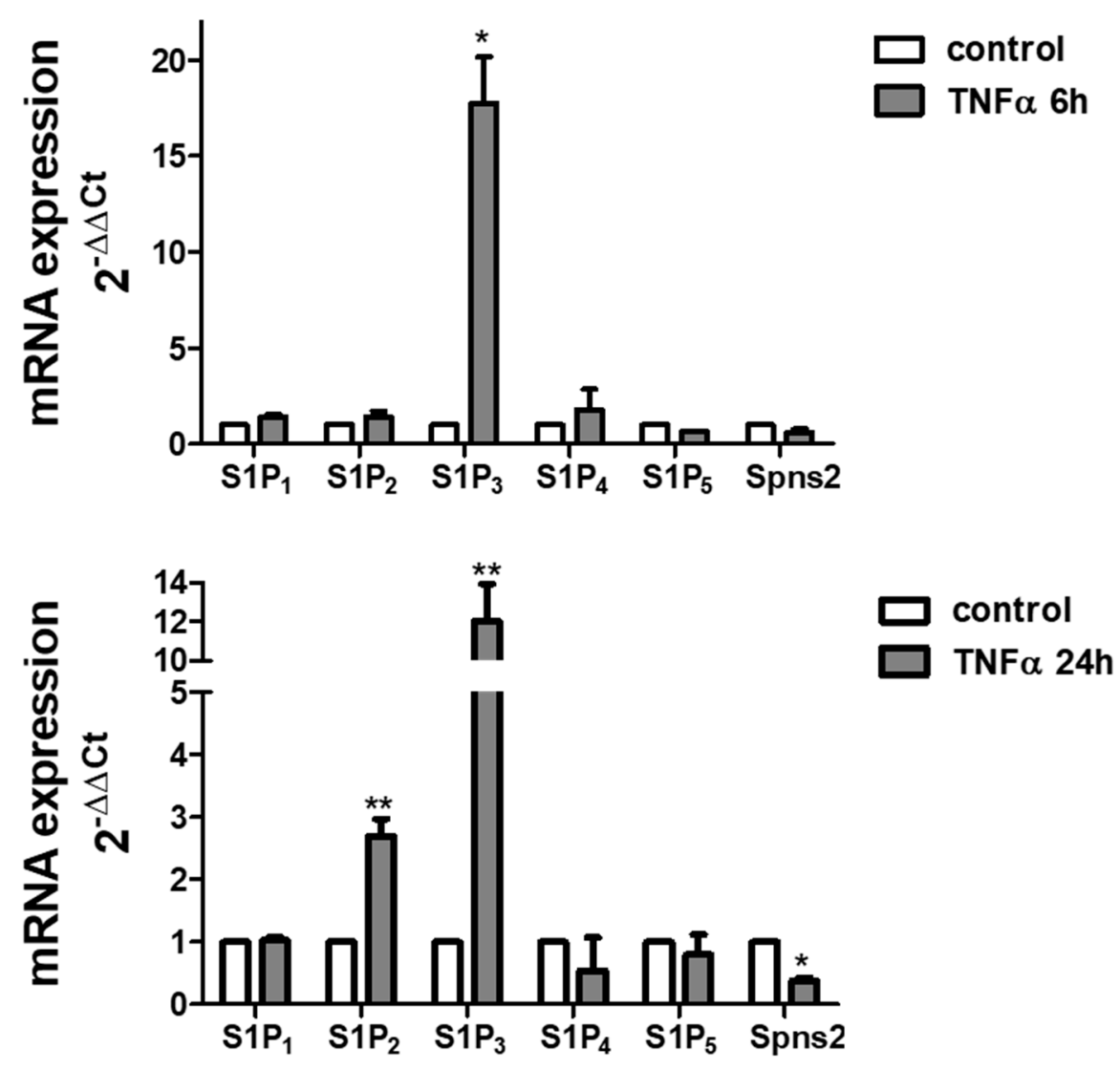

Figure 3. TNF $\alpha$ modulates S1P signalling. Quantitative mRNA analysis was performed by real-time PCR in total RNA extracted from C2C12 myotubes stimulated or not with $100 \mathrm{ng} / \mathrm{mL} \mathrm{TNF} \alpha$ for the indicated time intervals $(6 \mathrm{~h}$ and $24 \mathrm{~h})$. mRNA quantitation of S1PR $\left(\mathrm{S}_{1} \mathrm{P}_{1}, \mathrm{~S}_{\mathrm{P}}, \mathrm{S}_{2} \mathrm{P}_{3}, \mathrm{~S}_{\mathrm{P}} \mathrm{P}_{4}\right.$ and $\mathrm{S}_{1} \mathrm{P}_{5}$ ) and $\mathrm{S} 1 \mathrm{P}$ specific transporter, Spns2, was based on the $2^{-\Delta \Delta \mathrm{Ct}}$ method, using individual enzyme or Spns2 of the unchallenged specimen as calibrator. Data are the mean \pm SEM of three independent experiments performed in triplicate. The increase in $\mathrm{S}_{2} \mathrm{P}_{2}$ and $\mathrm{S}_{1} \mathrm{P}_{3}$ and the decrease in Spns2 expression induced by TNF $\alpha$ were statistically significant by Student's $t$ test ${ }^{*} p<0.05$; ** $p<0.01)$. 
The potential role of SK1 activation on the atrophic action induced by the cytokine was then examined. To this aim, C2C12 myotubes were treated with $10 \mu \mathrm{M}$ PF-543, specific inhibitor of SK1. Interestingly, treatment with the inhibitor completely reverted the reduction in MHC levels induced by TNF $\alpha$, suggesting a key role of SK1 in the atrophic effect of the cytokine (Figure 4a). In accordance, SK1 inhibition abolished the increase in the autophagic marker LC3-II induced by TNF $\alpha$ (Figure 4b). Accordingly, when TNF $\alpha$ was added in the presence of SK1 inhibitor PF-543, RMP was not significantly modified compared to that recorded from cells treated with TNF $\alpha$ alone, suggesting that this effect is barely associated with S1P formation (Figure 4c, Table S1). However, the pre-treatment with PF-543 completely reverted the effect of TNF $\alpha$ on $R_{m}$, whose values became even larger than those measured in control myotubes, suggesting the involvement of SK1/S1P pathway in this TNF $\alpha$-induced effect. Similarly, pre-treatment with PF-543 completely hindered the effect of TNF $\alpha$ on $C_{m}$. In accordance, the $C_{T} / C_{s}$ ratio calculated from myotubes treated with TNF $\alpha$ when SK1 was inhibited was similar to that measured in control and statistically different to that measured with TNF $\alpha$ alone (Figure 1c). These results indicate that $\mathrm{TNF} \alpha$ reduces the $\mathrm{Cm}$, mainly affecting T-tubular surface via S1P axis. In addition, the effect of TNF $\alpha$ on $\mathrm{K}^{+}$currents was completely reverted by SK1 inhibition, suggesting the involvement of the enzyme in this effect. These data are summarized in the I-V plots (Figure $4 \mathrm{~d}$ ) where each point represents the mean \pm SD of the current values measured at the end of the test pulse for all the experiments conducted, reported as a function of the voltage step applied. Of note, the inhibition of SK1 seems to be very effective in hindering $\mathrm{TNF} \alpha$ action on $\mathrm{K}^{+}$currents, since data points related to this treatment (filled circles) mostly overlap the control data (open diamonds). Although TNF $\alpha$ does not significantly affect $I_{\mathrm{Ca}}$ occurrence in our preparations (filled diamonds), when SK1 was inhibited an increase in current amplitude, both in the absence and presence of the cytokine (Figure $4 \mathrm{~d}$, open and filled circles, respectively), was observed. These results demonstrate that the $\mathrm{TNF} \alpha$-mediated atrophic effect strictly depends on the activation of SK1 in skeletal muscle.

However, the obtained findings showed that SK1 is not implicated in the metabolic shift induced by TNF $\alpha$. Indeed, from the PCA score plot reported in Figure 4e, it is clearly evident that the exo-metabolome fingerprint of the cells is not significantly influenced by pre-treatment with $10 \mu \mathrm{M}$ PF-543, indicating that the blockade of SK1 does not significantly affect the glycolytic shift (Figure 4e) nor the extracellular aminoacid content (Figure S2) induced by the cytokine.

Since TNF $\alpha$ is responsible for a deep modulation of S1PR expression in C2C12 myotubes, we then examined whether the atrophic action exerted by the cytokine was S1PRmediated. For this purpose, the content of MHC and LC3-II was evaluated in myotubes challenged with TNF $\alpha$ in the presence or absence of $10 \mu \mathrm{M}$ W146, selective antagonist of $\mathrm{S} 1 \mathrm{P}_{1}, 1 \mu \mathrm{M}$ JTE013, that selectively blocks $\mathrm{S}_{2} \mathrm{P}_{2}, 5 \mu \mathrm{M}$ CAY10444, selective $\mathrm{S}_{1} \mathrm{P}_{3}$ antagonist or $1 \mu \mathrm{M}$ VPC23019, selective $\mathrm{S}_{1} \mathrm{P}_{1} / \mathrm{S}_{1} \mathrm{P}_{3}$ antagonist. The results illustrated in Figure 5 show that the atrophic effect of $\mathrm{TNF} \alpha$ was abrogated by $\mathrm{S}_{3} \mathrm{P}_{3}$ blockade and not affected by $\mathrm{S}_{1} \mathrm{P}_{1}$ or $\mathrm{S}_{1} \mathrm{P}_{2}$ inhibition, suggesting a role of $\mathrm{S}_{3} \mathrm{P}_{3}$ in $\mathrm{TNF} \alpha$-induced response.

The possible involvement of $\mathrm{S}_{3} \mathrm{P}_{3}$ in the electrophysiological changes induced by $\mathrm{TNF} \alpha$ was then investigated. Figure 6 a shows results obtained when TNF $\alpha$ was added in the presence of $1 \mu \mathrm{M}$ VPC23019: the RMP value was not affected by the presence of the ${\mathrm{S} 1 \mathrm{P}_{3}}_{3}$ antagonist since $\mathrm{TNF} \alpha$ was still able to depolarize the membrane. In contrast, $\mathrm{R}_{\mathrm{m}}$ values evaluated in C2C12 myotubes treated with TNF $\alpha$ in the presence of VPC23019 were similar to those evaluated in control myoblasts, indicating that TNF $\alpha$ was no more effective in altering membrane resistance when $\mathrm{S}_{1} \mathrm{P}_{3}$ was blocked. Similarly, pre-treatment with VPC23019 entirely abolished the effect of TNF $\alpha$ on $C_{m}$. Accordingly, in myotubes where $\mathrm{S}_{1} \mathrm{P}_{3}$ was blocked, the treatment with $\mathrm{TNF} \alpha$ did not determine a significantly different $\mathrm{C}_{\mathrm{T}} / \mathrm{C}_{\mathrm{S}}$ ratio in respect to control but was significantly higher compared to that estimated from $\mathrm{C} 2 \mathrm{C} 12$ myotubes treated with $\mathrm{TNF} \alpha$ alone. These results show that $\mathrm{TNF} \alpha$ distresses the T-tubular surface via $\mathrm{S}_{3} \mathrm{P}_{3}$ signalling. 
a)

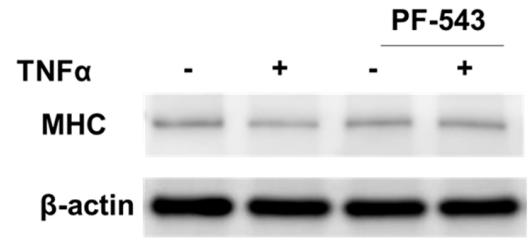

b)

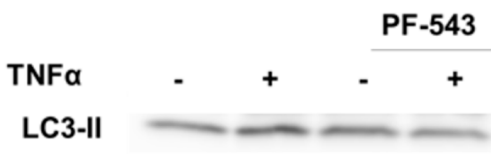

$\beta$-actin

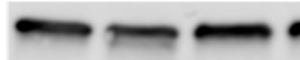

c)

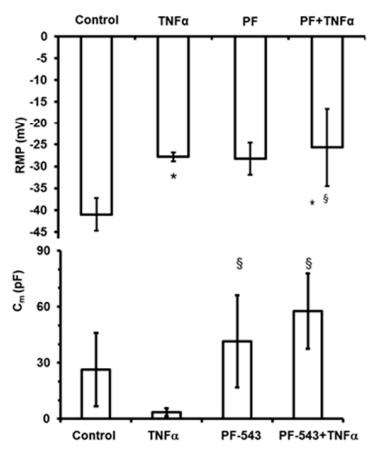

d)

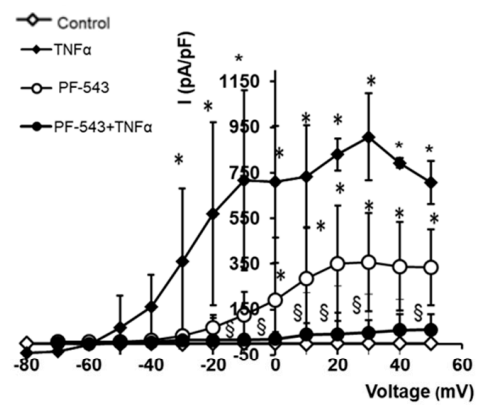

e)
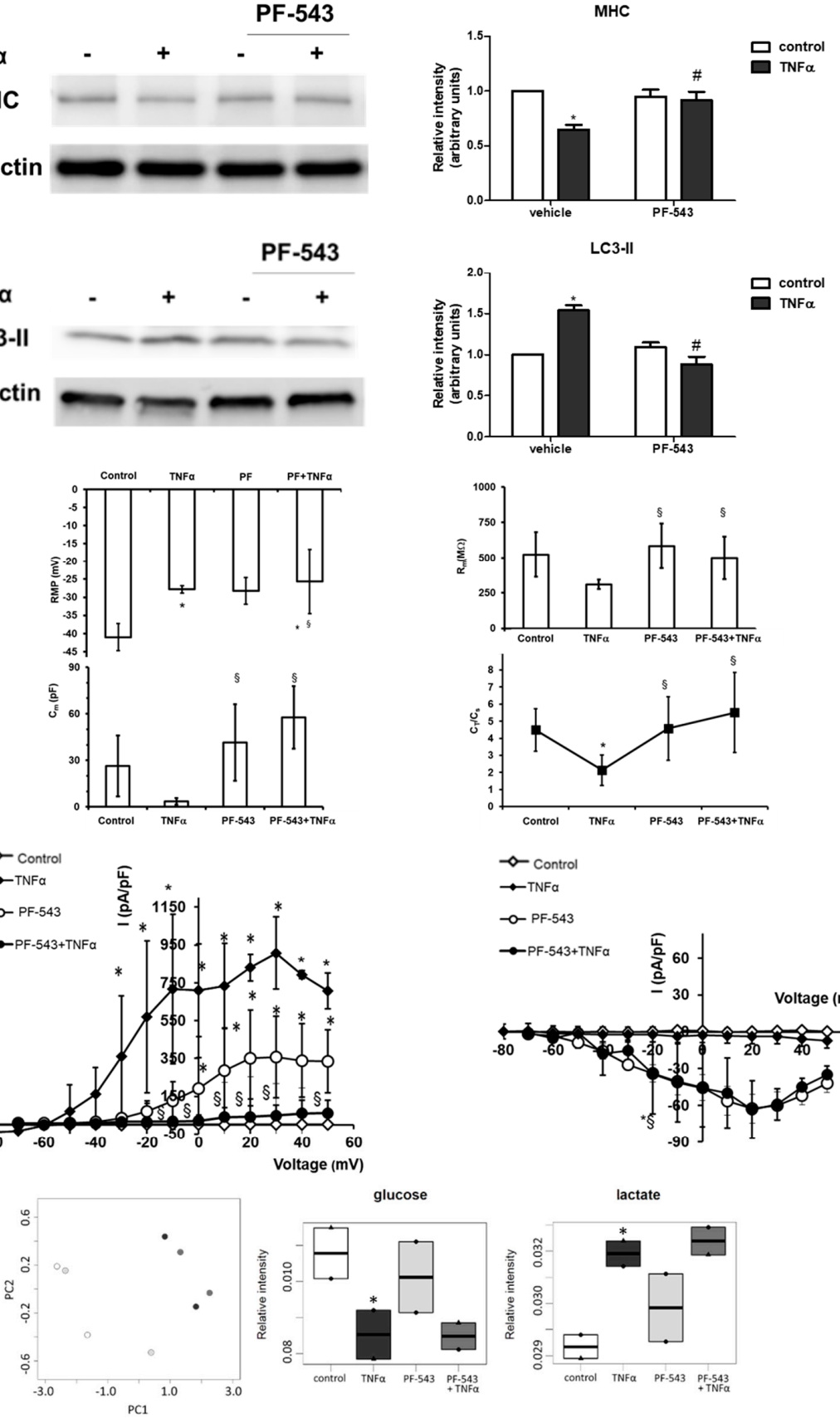

$\square$ control
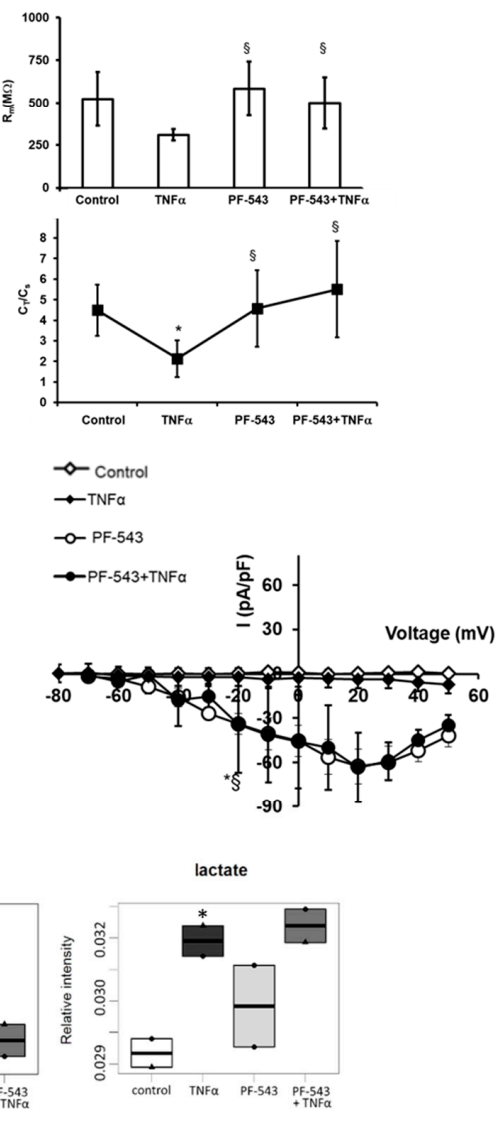

Figure 4. SK1 is involved in TNF $\alpha$-induced effect in $\mathrm{C} 2 \mathrm{C} 12$ myotubes. C2C12 myotubes were pretreated with SK1 specific inhibitor PF-543 $(10 \mu \mathrm{M})$ for $1 \mathrm{~h}$ before being challenged with $100 \mathrm{ng} / \mathrm{mL}$ TNF $\alpha$ for $24 \mathrm{~h}$. The content of MHC (a) and LC3-II (b) was analyzed by Western blotting of whole cell lysates. A blot representative of three independent experiments with analogous results is shown. The histograms represent the densitometric analysis of at least three independent experiments; Data are the mean \pm SEM and are reported as protein expression normalized to $\beta$-actin, -fold change over control (set as 1). The effect of SK1 inhibition by PF-543 on TNF $\alpha$ atrophic effect is statistically significant by two-way ANOVA followed by Bonferroni's post hoc test (\# $p>0.05$ ). (c) RMP, $\mathrm{R}_{\mathrm{m}}$, $\mathrm{C}_{\mathrm{m}}$ and $\mathrm{C}_{\mathrm{T}} / \mathrm{C}_{\mathrm{s}}$ ratio in the different conditions. All of the results and number of cells investigated are listed in Table S1 as mean \pm SD. ${ }^{*}$ Indicates $p<0.05$ vs. control; $\S$ indicates $p<0.05$ vs. TNF $\alpha$; (One-way ANOVA and Bonferroni's post hoc test). (d) Left panel: overall I-V plots related to $\mathrm{K}^{+}$ currents measured in all of the experiments conducted in any conditions. ${ }^{*} p<0.05$ vs. control, $\S p<0.05$ PF-543 + TNF $\alpha$ vs. TNF $\alpha$ (two-way ANOVA and Bonferroni's post hoc test) ( $n=5$ to 7 for the different treatments). Right panel: Overall $\mathrm{I}-\mathrm{V}$ plots related to $\mathrm{Ca}^{2+}$ currents measured in all of 
the experiments conducted in any conditions ( $n=4$ to 7 for the different treatments). ${ }^{*} p<0.05$ vs. control (two-way ANOVA and Bonferroni's post hoc test). Error bars are shown when their size is bigger than the symbol. (e) Left panel: Metabolomic phenotyping of conditioned media (exo-metabolome) of C2C12 myotubes treated or not with $100 \mathrm{ng} / \mathrm{mL} \mathrm{TNF} \alpha$ for $24 \mathrm{~h}$. Score plots of PCA: PC1 vs. PC2. In the score plots, each dot represents a different sample, and each color represents a different group of samples—white: control; dark grey: TNF $\alpha$; light grey:PF-543; medium gray: PF- $543+\mathrm{TNF} \alpha$. Right panels: boxplot of the metabolites involved in glycolysis. Changes in metabolite levels caused by TNF $\alpha$ were statistically significant by paired Wilcoxon test, $\left({ }^{*} p<0.05\right)$.

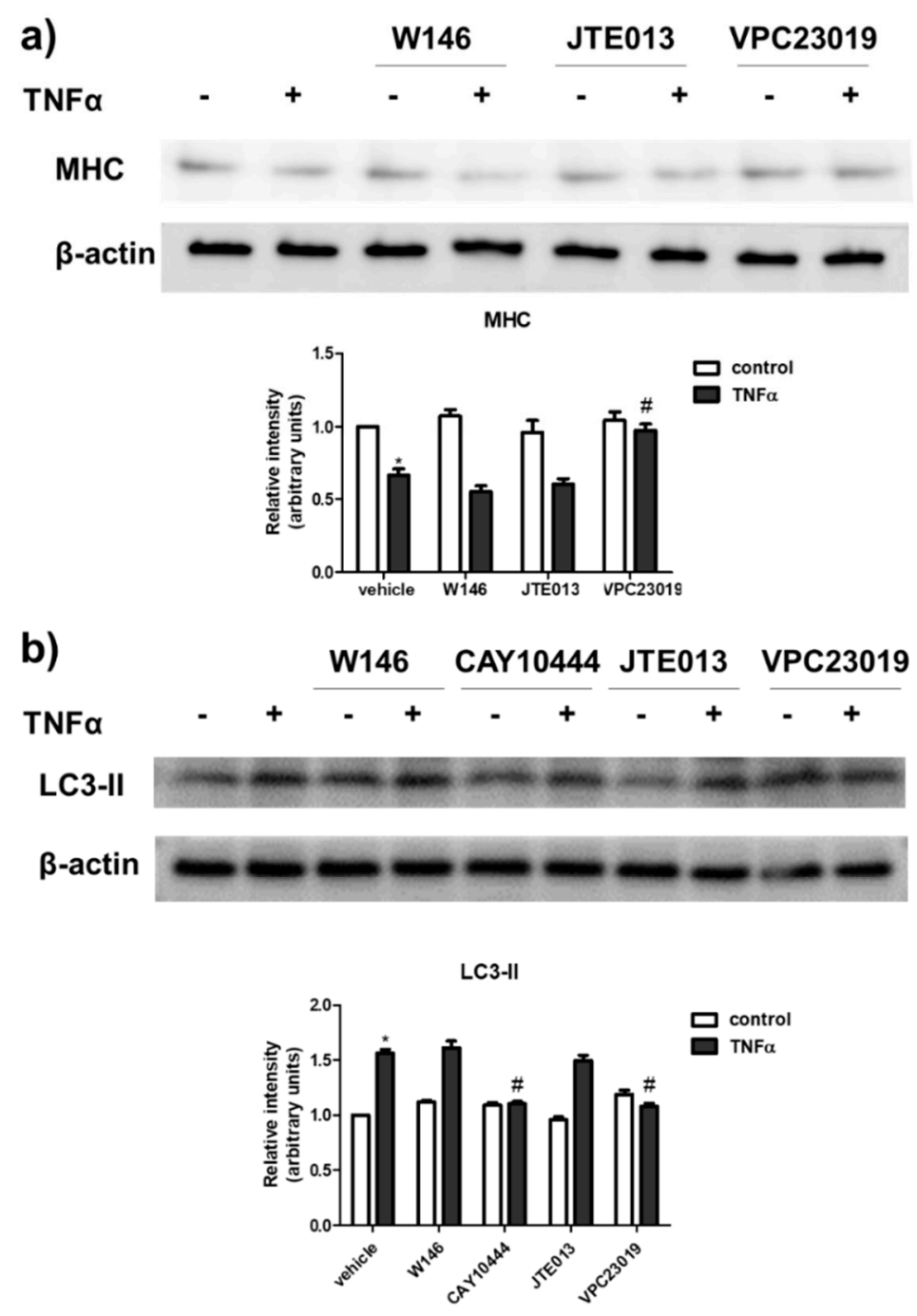

Figure 5. $\mathrm{S}_{1} \mathrm{P}_{3}$ is involved in $\mathrm{TNF} \alpha$-induced effect in $\mathrm{C} 2 \mathrm{C} 12$ myotubes. $\mathrm{C} 2 \mathrm{C} 12$ myotubes were pre-treated with S1PR specific antagonists $\left(10 \mu \mathrm{M}\right.$ W146, selective antagonist of $\mathrm{S}_{1} \mathrm{P}_{1}$, or $1 \mu \mathrm{M}$ JTE013, selective $\mathrm{S} 1 \mathrm{P}_{2}$ antagonist, or $5 \mu \mathrm{M}$ CAY10444, selective $\mathrm{S}_{3} \mathrm{P}_{3}$ antagonist or $1 \mu \mathrm{M}$ VPC23019, selective $\mathrm{S} 1 \mathrm{P}_{1} / \mathrm{S} 1 \mathrm{P}_{3}$ antagonist) for $1 \mathrm{~h}$ before being challenged with $100 \mathrm{ng} / \mathrm{mL} \mathrm{TNF} \alpha$ for $24 \mathrm{~h}$. The content of MHC (a) and LC3-II (b) was analysed by Western blotting of whole cell lysates. A blot representative of three independent experiments with analogous results is shown. The histograms represent the densitometric analysis of at least three independent experiments; data are the mean \pm SEM and are reported as protein expression normalized to $\beta$-actin, -fold change over control (set as 1 ). The effect of $\mathrm{S1P}_{3}$ inhibition by CAY10444 or VPC23019 on TNF $\alpha$ atrophic effect is statistically significant by two-way ANOVA followed by Bonferroni's post hoc test (\# $p>0.05)$. 
a)
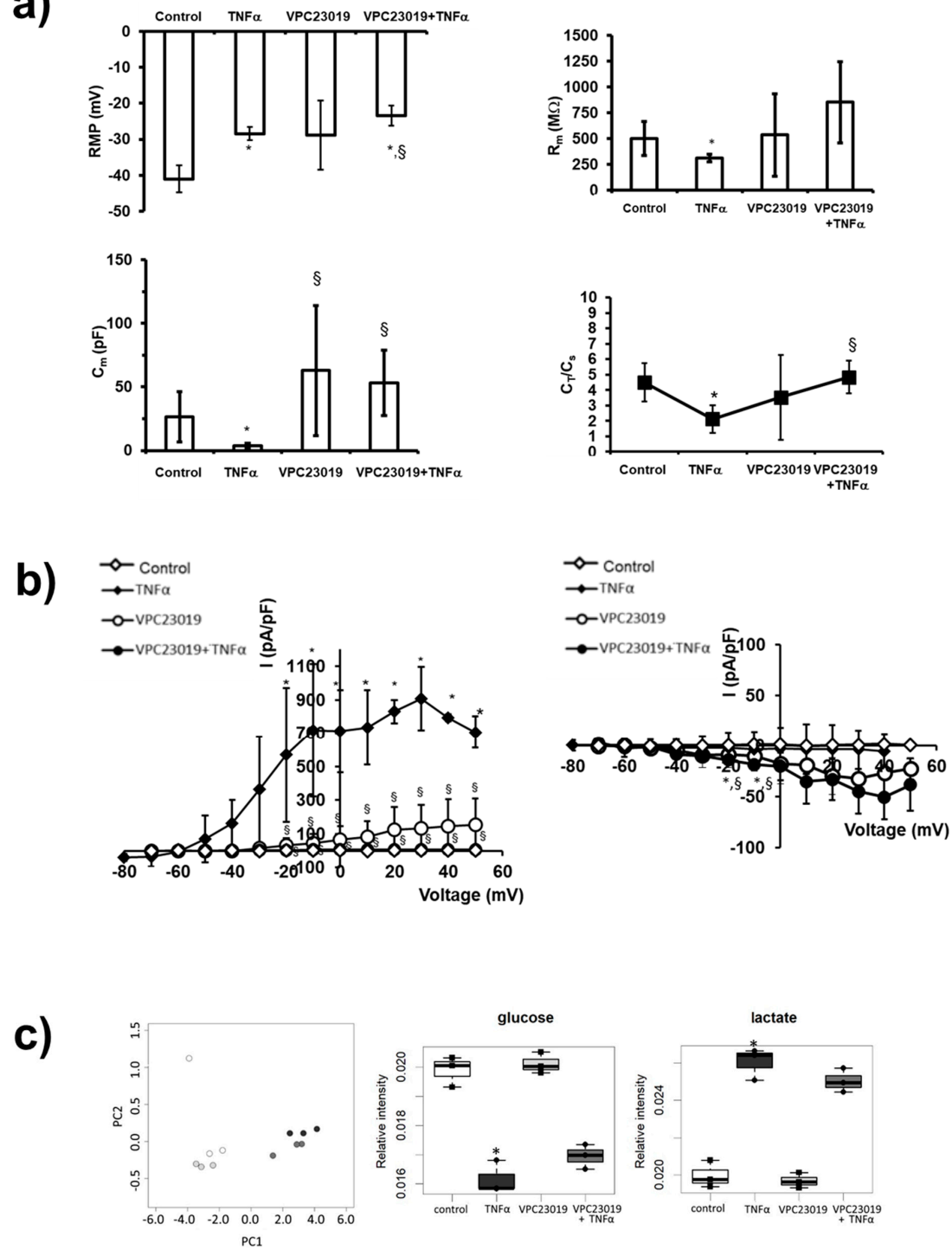

Figure 6. Role of $\mathrm{S}_{1} \mathrm{P}_{3}$ in TNF $\alpha$-induced effect in $\mathrm{C} 2 \mathrm{C} 12$ myotubes. (a) $\mathrm{RMP}, \mathrm{R}_{\mathrm{m}}, \mathrm{C}_{\mathrm{m}}$ and $\mathrm{C}_{\mathrm{T}} / \mathrm{C}_{\mathrm{s}}$ ratio in the different conditions. All of the results and number of cells investigated are listed in Table S1 as mean \pm SD. ${ }^{*}$ Indicates $p<0.05$ vs. control; $\S$ indicates $p<0.05$ vs. TNF $\alpha$; (One-way ANOVA and Bonferroni's post hoc test). (b) Left panel: overall I-V plots related to $\mathrm{K}^{+}$currents measured in all the experiments conducted in any conditions. ${ }^{*} p<0.05$ vs. control, $\S p<0.05$ VPC23019 + TNF $\alpha$ vs. TNF $\alpha$ (two-way ANOVA and Bonferroni's post hoc test) ( $n=3$ to 7 for the different treatments). Right panel: Overall $\mathrm{I}-\mathrm{V}$ plots related to $\mathrm{Ca}^{2+}$ currents measured in all the experiments conducted in any conditions $(n=3$ to 7 for the different treatments). ${ }^{*} p<0.05$ vs. control; $\S p<0.05$ vs. TNF $\alpha$ (two-way ANOVA and Bonferroni's post hoc test). Error bars are shown when their size is bigger than the symbol. (c) Left panel: Metabolomic phenotyping of conditioned media (exo-metabolome). Score plots of PCA: PC1 vs. PC2. In the score plots, each dot represents a different sample, and each colour represents a different group of samples—-white: control; dark grey: TNF $\alpha$; light grey: VPC23019; medium grey: VPC23019+TNF $\alpha$. Right panels: boxplot of the metabolites involved in glycolysis. Changes in metabolite levels caused by $\mathrm{TNF} \alpha$ were statistically significant by paired Wilcoxon test, $\left({ }^{*} p<0.05\right)$.

Moreover, TNF $\alpha$ effect on the outward currents was hindered by VPC23019 pretreatment (Figure $6 \mathrm{~b}$ ): the data points related to the current amplitudes recorded from $\mathrm{TNF} \alpha$-treated myotubes in the presence of VPC23019 (filled circles) are not distinct from those obtained in control (open diamonds) (Figure $6 \mathrm{~b}$, left I-V plot). Regarding $I_{\mathrm{Ca}} \mathrm{Oc}-$ currence, cell treatment with $\mathrm{S} \mathrm{P}_{3}$ antagonist alone (open circles) caused an increase in current amplitude that was not significantly modified when TNF $\alpha$ was added (filled circles) (Figure $6 \mathrm{~b}$, right I-V plot). 
The PCA score plot reported in Figure $6 \mathrm{c}$ shows that when $\mathrm{S}_{3} \mathrm{P}_{3}$ signalling was blocked by VPC23019 $(1 \mu \mathrm{M})$, exo-metabolome fingerprint alteration induced by TNF $\alpha$ was not significantly altered. In agreement, the metabolic shift (Figure 6c) or the modulation of the extracellular aminoacid content (Figure S3) induced by $\mathrm{TNF} \alpha$ were unaltered by $\mathrm{S}_{3} \mathrm{P}_{3}$ blockade.

Altogether, these data support the view that TNF $\alpha$ exploits the SK1-dependent insideout S1P signalling to transactivate $\mathrm{S1P}_{3}$ in an autocrine/paracrine fashion in order to mediate skeletal muscle atrophy and the related functional features, but not for transducing the metabolic shift induced by the cytokine.

\section{Discussion}

Skeletal muscle represents the most abundant tissue of the human body, whose function is necessary for many fundamental biological processes from movement to respiration. A tight balance between protein synthesis and degradation is required to maintain muscle homeostasis [37]. Three main pathways are involved in skeletal muscle protein degradation: ubiquitin-mediated proteasome degradation, autophagy and calcium-activated protease calpains [37]. Literature findings support a growing interest in autophagy as a mediator of skeletal muscle atrophy [38]; recently, it has been showed that autophagy, although involved in cachexia, is not required in muscle atrophy and it appears to play a critical role in myofiber maintenance [39,40] for skeletal muscle development and regeneration [41].

Consolidated literature data support a crucial role of the bioactive sphingolipid S1P in skeletal muscle biology [21]. S1P indeed plays a crucial role in satellite cell activation [22] and proliferation [42], but also on myoblast differentiation [25] and migration [26].

In the present manuscript, we provide experimental evidence that S1P signalling is deeply modulated by $\mathrm{TNF} \alpha$, which induces atrophy in $\mathrm{C} 2 \mathrm{C} 12$ myotubes: the cytokine was capable of up-regulating the mRNA levels of $\mathrm{S}_{2} \mathrm{P}_{2}$ and even more those of $\mathrm{S} \mathrm{P}_{3}$ at $6 \mathrm{~h}$ and $24 \mathrm{~h}$ of treatment while down-regulated SK2 transcripts at $24 \mathrm{~h}$. Short time of incubation with the cytokine increased the phosphorylated form of SK1, readout of its activation. Notably, the involvement of S1P signalling axis in TNF $\alpha$-induced skeletal muscle atrophy was highlighted since, when $\mathrm{SK} 1$ and $\mathrm{S}_{3} \mathrm{P}_{3}$ were inhibited, the autophagy marker increase and the electrophysiological changes induced by the cytokine in C2C12 myotubes were significantly altered.

$\mathrm{TNF} \alpha$, initially named cachectin, is one of the most characterized cytokines that is able to promote anorexia [43] and skeletal muscle wasting [44], mainly through the NF-kB pathway. TNF $\alpha$, at high doses, has been reported to induce muscle wasting, altering the ability of satellite cells to differentiate into myotubes [32]. In this work, TNF $\alpha$, at high doses, down-regulated the protein level of MHC, upregulated the autophagy marker LC3-II and was also able to induce extensive changes in the electrophysiological properties of C2C12 myotubes. TNF $\alpha$ challenge decreased the membrane potential RMP, capacitance $\mathrm{C}_{\mathrm{m}}$ and $\mathrm{Ca}^{2+}$ currents. This feature is well related to muscle atrophy and is usually due to a major reduction in transverse (T) tubular area [34]. During muscle wasting, the shortage of energy metabolism may contribute to dysfunction and impairment of ion channels and $\mathrm{Ca}^{2+}$, which is also supported by TEM analysis showing mitochondrial decrease and misplacement [34]. Membrane potentials recorded in experiments performed in denervated fibers supported a leaky sarcolemma and an increase in intracellular $\mathrm{Ca}^{2+}$ concentration, thus reducing membrane excitability [45]. A reduced resting membrane resistance Rm together with the reduced muscle fibre diameter could explain the reduced excitability found in muscle of cachectic patients [46]. A recent report showed that skeletal muscle oxidation of the calcium channel RyR1 (ryanodine receptor and calcium release channel) leads to leaky channels and drives to inefficient muscle activity [47].

In the present manuscript, NMR-based metabolomics provided a clear picture of the deep remodelling of $\mathrm{C} 2 \mathrm{C} 12$ myotubes metabolism towards aerobic glycolysis induced by $\mathrm{TNF} \alpha$ challenge characterized by significantly reduced extracellular glucose content and increased levels of lactate. In addition, a marked reduction in the extracellular aminoacid 
content was observed. These findings are in agreement with previously reported role of $\mathrm{TNF} \alpha$ in the utilization of glucose, formation of lactate [48] and nitrogen metabolism [49]. Notably, in the serum of elderly people affected by age-associated skeletal muscle atrophy, low levels of tryptophan and increased proline concentrations have been reported $[50,51]$. $\mathrm{TNF} \alpha$ plays a crucial role in the metabolic alteration that occurs in cancer cachexia [52], causing an increase in expenditure of energy, altered lipid and carbohydrate metabolism and insulin resistance. In vitro experiments performed in skeletal muscle showed that $\mathrm{TNF} \alpha$ promotes a futile cycle linked to the co-activation of phosphofructokinase- 1 and fructose-1,6-bisphosphatase, resulting in ATP consumption, further promoting resting energy expenditure [48].

TNF $\alpha$, at low doses, has, on the contrary, been showed to be physiologically involved in skeletal muscle adaptation to exercise and in satellite cell differentiation $[53,54]$. We previously demonstrated that $\mathrm{TNF} \alpha$, at low doses, enhances differentiation of murine $\mathrm{C} 2 \mathrm{C} 12$ myoblasts, increasing the expression of the early myogenic marker myogenin and MHC at early time points of differentiation [31]. Furthermore, SK has been previously shown to mediate multiple actions of TNF $\alpha$ such as protection from apoptotic cell death [55], proliferation [56] and inflammation [57].

In the present study, when $\mathrm{SK} 1$ and $\mathrm{S}_{1} \mathrm{P}_{3}$ were pharmacologically blocked, the ability of TNF $\alpha$ in increasing LC3-II and reducing MHC expression levels, membrane potential, capacitance and $\mathrm{K}^{+}$currents was inhibited, highlighting the involvement of S1P signalling in TNF $\alpha$-induced contractile protein degradation and T-tubular surface distress. Therefore, it has been demonstrated that in myotubes, obtained by differentiating myoblasts for 5 days, $\mathrm{TNF} \alpha$, via the $\mathrm{SK}_{1} / \mathrm{S}_{1} \mathrm{P}_{3}$ axis, induced an increase in LC3-II that parallels the reduction in MHC provoked by the cytokine, suggesting a role of autophagy in this type of skeletal muscle atrophy. However, future experiments are needed to finely and comprehensively dissect the contribution of TNF $\alpha$ and S1P signalling in the complex regulation of skeletal muscle autophagy. Moreover, it cannot be excluded that the reduction in MHC levels induced by TNF $\alpha$ via the $\mathrm{SK} 1 / \mathrm{S}_{1} \mathrm{P}_{3}$ axis could be ascribed, at least in part, to a proapoptotic role of the cytokine in myotubes. Pre-incubation with the SK1 inhibitor PF-543 altered $\mathrm{Ca}^{2+}$ currents in the absence of $\mathrm{TNF} \alpha$, supporting the hypothesis that, in control conditions, SK1 activity and the consequent S1P formation may help to prevent an excessive $\mathrm{Ca}^{2+}$ entry through voltage dependent $\mathrm{Ca}^{2+}$ channels. Remarkably, the cytokine-induced metabolic remodelling appeared not to depend on the S1P axis, at least at these times of incubation, highlighting the complexity of the mechanism of action of TNF $\alpha$ in skeletal muscle atrophy, only partially mediated by the sphingolipid signalling.

The here reported role of S1P axis in TNF $\alpha$-induced atrophy resembles that played by the bioactive sphingolipid in TGF $\beta$-induced fibrosis in skeletal muscle [58]. Although in myoblasts, the SK/S1P axis, via $\mathrm{S}_{2} \mathrm{P}_{2}$ engagement, is physiologically required for the achievement of myogenic differentiation of C2C12 [28,31,59], SK1 activity was shown to be a mediator of the pro-fibrotic effect of TGF $\beta$ in myoblasts [58]. Interestingly, the different biological outcome mediated by SK1/S1P signalling axis after TGF $\beta$ treatment strictly depends on the remodelling of S1PR expression pattern exerted by the cytokine: concomitantly with SK1 up-regulation, $\mathrm{TGF} \beta$ upregulates $\mathrm{S}_{1} \mathrm{P}_{3}$ that becomes the prevailing expressed receptor, and via the $\mathrm{S} 1 \mathrm{P}$ inside-out signalling this receptor is responsible for the transmission of the cytokine pro-fibrotic action [58].

De Larichaudy et al. previously demonstrated that ceramide mediates TNF $\alpha$ skeletal muscle atrophy in differentiated L6 and C2C12 myotubes [33]. They showed that in L6 myotubes, exogenous S1P exerts an antagonistic action with respect to ceramide on myotube surface and creatine kinase activity. Inhibition of SK activity by dimethylsphingosine increased the effects of $\mathrm{TNF} \alpha$, highlighting that S1P plays an opposite role of ceramide. Moreover, the authors showed that treatment with FTY720 had negative effects on myotubes [33]. S1P has been shown to act as trophic factor in skeletal muscle, being capable of delaying the progression of denervation induced atrophy [30] and improving muscle regeneration in an mdx mice model of muscular dystrophy [24]. In skeletal muscles of 
animals bearing the C26 tumor, a well-known model of cancer cachexia, and in C2C12 myotubes treated with dexamethasone, a down-regulation of active SK1 was observed, while an up-regulation of Spns 2 and $\mathrm{S}_{2} \mathrm{P}_{2}$ occurred. Interestingly, exogenous S1P counteracted the effect of dexamethasone reducing atrogin expression, while S1P alone increased the level of the atrophy markers [60]. These contrasting literature data might depend on different experimental conditions such as time of incubations or employed concentrations. Data here reported confirm the highly versatile biological outcome of the SK1/S1P/S1PR axis in skeletal muscle cells. After TNF $\alpha$ treatment at high doses, a deep S1PR remodelling occurs and the cytokine exerts its atrophic effect by ligation to $\mathrm{S}_{1} \mathrm{P}_{3}$, which is profoundly upregulated by TNF $\alpha$. S1PR remodelling indeed appears to be the crucial aspect to mechanistically explain the different biological outcomes brought about by TNF $\alpha$. Interestingly, recent findings in prostate cancer cachectic patients showed increased levels of cytokines in circulation: serum TNF $\alpha$ concentration was about $6.54 \mathrm{pg} / \mathrm{mL}$ [61]. Although these levels are far from that used in the present study in our in vitro experimental setting, it should be taken into account that the local tissue levels of TNF $\alpha$ in skeletal muscle could considerably differ from serum concentration of cachectic patients.

The present study opens innovative therapeutic perspectives for skeletal muscle wasting management, highlighting the role of S1P signalling in $\mathrm{TNF} \alpha$ induced atrophy.

\section{Materials and Methods}

\subsection{Materials}

All biochemicals, cell culture reagents, Dulbecco Modified Eagle Medium (DMEM), fetal bovine serum (FBS), protease inhibitor cocktail, bovine serum albumin (BSA) selective $\mathrm{S}_{1} \mathrm{P}_{2}$ antagonist JTE013, specific $\mathrm{S}_{1} \mathrm{P}_{1 / 3}$ antagonist VPC23019, specific inhibitor of SK1 PF-543, and myosin heavy chain (MHC) antibody were purchased from Merck Life Science (Burlington, MA, USA). Selective $\mathrm{S1P}_{1}$ antagonist W146 was from Avanti Polar Lipids (Alabaster, AL, USA). Recombinant TNF $\alpha$ was obtained from PeproTech (London, UK). Human specific TaqMan Gene Expression Assays employed for gene expression studies were purchased from Thermo Fisher Scientific INC (Waltham, MA, USA). Anti-SK1, antiSK2, anti-phospho-SK1 (Ser225) and anti-phospho-SK2 (Thr578) antibodies were from ECM Biosciences (Versailles, KY, USA). Secondary antibodies conjugated to horseradish peroxidase, anti-LC3 antibody and anti- $\beta$-actin antibodies were obtained from Santa Cruz Biotechnology (Santa Cruz, CA, USA).

\subsection{Cell Culture}

Murine C2C12 myoblasts were maintained in DMEM containing 10\% FCS, 2 mM 1glutamine, $100 \mu \mathrm{g} / \mathrm{mL}$ streptomycin and $100 \mathrm{U} / \mathrm{mL}$ penicillin at $37^{\circ} \mathrm{C}$ in $5 \% \mathrm{CO}_{2}$. To induce differentiation, confluent cells were cultured in DMEM without serum supplemented with $1 \mathrm{mg} / \mathrm{mL}$ BSA for 5 days. The myotubes obtained were then treated with $25-100 \mathrm{ng} / \mathrm{mL}$ $\mathrm{TNF} \alpha$ for $24 \mathrm{~h}$ to induce atrophy. In some of the experiments, cells were pre-treated with $10 \mu \mathrm{M}$ W146, $1 \mu \mathrm{M}$ JTE013, $5 \mu \mathrm{M}$ CAY10444, $1 \mu \mathrm{M}$ VPC23019, $10 \mu \mathrm{M}$ PF-543, 1 h before agonist stimulation.

\subsection{Western Blot Analysis}

C2C12 myotubes were collected and lysed for $30 \mathrm{~min}$ at $4{ }^{\circ} \mathrm{C}$ in a buffer containing $50 \mathrm{mM}$ Tris, pH 7.5, $120 \mathrm{mM} \mathrm{NaCl}, 1 \mathrm{mM}$ EDTA, $6 \mathrm{mM}$ EGTA, $15 \mathrm{mM} \mathrm{Na} \mathrm{P}_{2} \mathrm{O}_{7}, 20 \mathrm{mM} \mathrm{NaF}$, $1 \%$ Nonidet and protease inhibitor cocktail before being centrifuged at $10,000 \times g, 15 \mathrm{~min}$ $4{ }^{\circ} \mathrm{C}$. Samples resuspended in Laemmli's SDS (sodium dodecyl sulphate) sample buffer were subjected to SDS-PAGE before transfer of proteins to PVDF (polyvinylidene difluoride) membranes $[62,63]$. PDVF membranes were incubated overnight with the primary antibodies at $4{ }^{\circ} \mathrm{C}$ and then with specific secondary antibodies for $1 \mathrm{~h}$ at room temperature. Binding of the antibodies with the specific proteins has been detected by chemiluminescence. 


\subsection{Quantitative Real-Time Reverse Transcription PCR}

Total RNA from C2C12 myotubes was extracted using a TRI Reagent ${ }^{\circledR \circledR}$ RNA Isolation Reagent. Then, $1-2 \mu \mathrm{g}$ of RNA was reverse transcribed using the high capacity cDNA reverse transcription kit (Applied Biosystems, Foster City, CA, USA). TaqMan gene expression assays were used to perform real-time $\mathrm{PCR}$ in order to quantify the mRNA expression of S1P metabolism enzymes (SK1, SK2, SPL, SPP1, SPP2), S1PR (S1P $, \mathrm{S} 1 \mathrm{P}_{2}, \mathrm{~S}^{\mathrm{P}} \mathrm{P}_{3}, \mathrm{~S}_{\mathrm{P}}$, $\mathrm{S} \mathrm{P}_{5}$ ) and $\mathrm{S1P}$ specific transporter Spns2. Each measurement was carried out in triplicate using the CFX96 Touch ${ }^{\mathrm{TM}}$ Real-Time PCR Detection System (Biorad, Hercules, CA, USA) as described previously $[64,65]$, by simultaneous amplification of the target sequence together with the housekeeping gene $\beta$-actin. The $2^{-\Delta \Delta \mathrm{Ct}}$ method was applied as a comparative method of quantification [66], and data were normalized to $\beta$-actin expression.

\subsection{NMR-Based Metabolomic Analyses}

Conditioned media were analysed using an untargeted ${ }^{1} \mathrm{H}-\mathrm{NMR}$-based metabolomic approach $[67,68]$. Samples for NMR analyses were prepared according to procedures developed to obtain highly reproducible samples for cell metabolomics [69].

Conditioned media were collected and immediately frozen at $-80^{\circ} \mathrm{C}$. Frozen samples were thawed in ice and shaken before use. NMR samples from conditioned media (exo-metabolome analysis) were prepared into $5.00 \mathrm{~mm}$ NMR tubes (Bruker BioSpin srl; Rheinstetten, Germany) by mixing an aliquot of $250 \mu \mathrm{L}$ of a sodium phosphate buffer (70 $\mathrm{mm} \mathrm{Na} 2 \mathrm{HPO}_{4} ; 20 \% v / v^{2} \mathrm{H}_{2} \mathrm{O} ; 4.6 \mathrm{~mm}$ TMSP, $\mathrm{pH}$ was adjusted to the final value of 7.4 using $1 \mathrm{~m} \mathrm{HCl}$ ) with $250 \mu \mathrm{L}$ of the medium.

NMR spectral acquisition and processing were performed according to optimized procedures for metabolomic analysis of growing media developed at CERM [67,68,70,71]. One-dimensional (1d) ${ }^{1} \mathrm{H}$ NMR spectra were acquired on conditioned media using a Bruker $600 \mathrm{MHz}$ spectrometer equipped with a $5 \mathrm{~mm}$ PATXI ${ }^{1} \mathrm{H}-{ }^{13} \mathrm{C}-{ }^{15} \mathrm{~N}$ and ${ }^{2} \mathrm{H}$-decoupling probe including a $z$-axis gradient coil, an automatic tuning-matching (ATM) and an automatic and refrigerate sample changer (SampleJet, Bruker BioSpin srl; Rheinstetten, Germany). ${ }^{1} \mathrm{H}$ NMR spectra were acquired at $300 \mathrm{~K}$ with water presaturation and a $1 \mathrm{~d}$ nuclear Overhauser enhancement spectroscopy (NOESY)- pulse sequence (noesygppr1d, Bruker). A total of 64 scans were used, with 98,304 data points, a spectral width of $18,028 \mathrm{~Hz}$, an acquisition time of $2.7 \mathrm{~s}$, a relaxation delay of $4 \mathrm{~s}$ and a mixing time of $0.1 \mathrm{~s}$.

The raw data were multiplied by a $0.3 \mathrm{~Hz}$ exponential line broadening and Fourier transformation were applied. Transformed spectra were automatically corrected for phase and baseline distortions. The calibration of the spectra was performed to the signal of TMSP at $0.00 \mathrm{ppm}\left({ }^{1} \mathrm{H}\right.$ chemical shift $)$.

Multivariate untargeted Principal Component Analysis (PCA) was performed on bucketed NMR spectra. To this aim, each spectrum (from 0.2 to $10.0 \mathrm{ppm}$ ) was segmented into $0.02 \mathrm{ppm}$ chemical shift bins and the corresponding spectral areas were integrated using the AMIX software (Bruker). The area of each bin was normalized to the total spectral area, calculated with the exclusion of water region (4.5-5.0 ppm). PCA was used to obtain an overview of the dataset, i.e., visualization in a reduced space and clusters detection.

The most abundant metabolites present in the spectra were assigned and their levels analyzed. The assignment procedure was made up using a NMR spectra library of pure organic compounds, stored reference NMR spectra of metabolites and literature data. Matching between new NMR data and databases was performed using the ASSURE software (Bruker, BioSpin srl; Rheinstetten, Germany). The relative concentrations of the various metabolites were calculated by integrating the corresponding signals in the spectra using a home-made R script. The non-parametric Wilcoxon test was used for the determination of the meaningful metabolites: a $p$-value of 0.05 was considered statistically significant. 


\subsection{Electrophysiology}

The membrane passive properties and transmembrane ion currents were analysed by the whole cell patch clamp technique. The patch pipettes were achieved by a vertical puller (Narishige, Tokyo, Japan) using borosilicate glass capillaries (GC150-15; Clark, Electromedical Instruments, Reading, UK). Pipettes were commonly filled with the following internal solution (mM): $130 \mathrm{KCl}, 10 \mathrm{NaH}_{2} \mathrm{PO}_{4}, 0.2 \mathrm{CaCl}_{2}, 1 \mathrm{EGTA}, 5 \mathrm{MgATP}$ and 10 HEPES (pH 7.2 with $\mathrm{KOH}$ ). The electrode resistance was 3-7 M . Electrophysiological experiments were performed on $\mathrm{C} 2 \mathrm{C} 12$ myotubes plated on glass coverslips and constantly

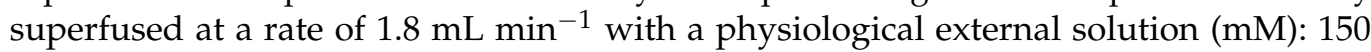
$\mathrm{NaCl}, 5 \mathrm{KCl}, 2.5 \mathrm{CaCl}_{2}, 1 \mathrm{MgCl}_{2}, 10 \mathrm{D}$-glucose and 10 HEPES (pH 7.4 with $\mathrm{NaOH}$ ). The set-up, Axopatch 200 B amplifier, A/D-D/A interfaces Digidata 1200; Pclamp 6 software (Axon Instruments, Foster City, CA, USA) and electronic device were as described in detail in previously published papers [65,72]. The data analysis was made by Clampfit 9 (Axon Instruments, Foster City, CA, USA) software. The resting membrane potential (RMP) was evaluated in the current clamp mode of the $200 \mathrm{~B}$ amplifier, with $\mathrm{I}=0$. The membrane passive properties were estimated in voltage-clamp by applying a voltage pulse of $\pm 10 \mathrm{mV}$ from a holding potential of $-70 \mathrm{mV}$. The decay of the evoked passive current [34] could be fitted by the sum of 2 exponential functions. These functions represent the time course of the surface and tubular membrane passive currents, $\mathrm{I}_{\mathrm{S}}$ and $\mathrm{I}_{\mathrm{T}}$, respectively [73]. The related time constants are $t_{s}=R_{S} C_{s}$ and $t_{T}=R_{T} C_{T}$, where $R_{s}$ and $R_{T}$ represent the resistances in parallel with $C_{s}$ and $C_{T}$, respectively; $C_{S}$ is the capacitance associated with the surface membrane and $C_{T}$ is the capacitance associated with the tubular membrane. The cell linear capacitance $C_{m}$, used as an index of the cell surface area (being the membrane-specific capacitance $1 \mu \mathrm{F} / \mathrm{cm}^{2}$ ), is calculated from the area beneath the capacitive transient current and is the overall result of $C_{s}+C_{T}$. The membrane resistance $\left(R_{m}\right)$ values were calculated from the steady-state membrane current $\left(\mathrm{I}_{\mathrm{m}}\right)$ as previously reported [72].

Ion currents were evoked in voltage-clamp mode. To record the delayed rectifier $\mathrm{K}^{+}$current $\left(I_{\mathrm{K}}\right)$, we used the physiological external solution with nifedipine (10 $\mu \mathrm{M})$ added to avoid the occurrence of L-type $\mathrm{Ca}^{2+}$ current. To record only $\mathrm{Ca}^{2+}$ current, $I_{\mathrm{Ca}}$, we used a $\mathrm{Na}^{+}$- and $\mathrm{K}^{+}$-free high-TEA external solution $(\mathrm{mM}): 10 \mathrm{CaCl}_{2}, 145$ tetraethylammonium bromide, 10 HEPES and a suitable filling pipette solution $(\mathrm{mM})$ : $150 \mathrm{CsBr}, 5 \mathrm{MgCl}_{2}, 10$ Ethylene-bis(oxyethylenenitrilo) tetraacetic acid (EGTA), 10 (4-(2hydroxyethyl)-1-piperazineethanesulfonic acid) (HEPES) $(\mathrm{pH}=7.2)$ [74]. In any case, we applied a pulse protocol of stimulation consisting of 1-s step voltage pulses, ranging from -80 to $50 \mathrm{mV}$, in $10 \mathrm{mV}$ increments starting from a HP $=-60 \mathrm{mV}$ for $I_{\mathrm{K}}$ or $-80 \mathrm{mV}$ for $I_{\mathrm{Ca}}$. $\mathrm{P} 4$ procedure was used to remove on-line capacitive and leak currents. The current amplitude values were normalized to $C_{m}$ to have a correct evaluation between records acquired from cells of different size. Thus, the ratio $I / C_{m}($ in $p A / p F)$ is intended as current density. All drugs were from Sigma Chemical (St. Louis, MO, USA). The experiments were performed at room temperature $\left(22^{\circ} \mathrm{C}\right)$.

\subsection{Statistical Analysis}

To perform densitometric analysis of the Western blot bands and graphical representations, ImageJ software and GraphPad Prism 6.0 (GraphPad Software, San Diego, CA, USA) were utilized, respectively. Statistical analysis was performed using Student's t test, oneway and two way ANOVA followed by Bonferroni's post hoc test and paired Wilcoxon test.

Supplementary Materials: Supplementary Materials can be found at https://www.mdpi.com/1422 $-0067 / 22 / 3 / 1280 /$ s1.

Author Contributions: Conceptualization, C.B. and C.D.; methodology, C.B., V.G. and R.S.; investigation, C.B., V.G., R.S., E.I., R.G., E.P. and F.C.; data curation, C.B., V.G. and R.S.; writing-original draft preparation, C.D. and C.B.; writing-review and editing, C.B., R.S., F.C., P.B. and C.D.; supervision, C.D. and P.B.; project administration, C.D.; funding acquisition, C.B., F.C., P.B. and C.D. All authors have read and agreed to the published version of the manuscript. 
Funding: This work was supported by Fondazione Cassa di Risparmio di Firenze to Chiara Donati, and funds from the University of Florence (Fondi di Ateneo-ex 60\%) to Paola Bruni, Chiara Donati, Caterina Bernacchioni and Francesca Cencetti. Veronica Ghini was supported by the AIRC fellowship for Italy.

Institutional Review Board Statement: Not applicable.

Informed Consent Statement: Not applicable.

Data Availability Statement: Data is contained within the article or supplementary material.

Acknowledgments: The authors took advantage of the newly established Molecular Medicine Facility of the Department of Experimental and Clinical Biomedical Sciences "Mario Serio" at the University of Florence. The facility was supported by a grant from the Italian Ministry of Education, University, and Research after the Department was awarded as one of the 180 Departments of Excellence in Italy.

Conflicts of Interest: The authors declare no conflict of interest.

$\begin{array}{ll}\text { Abbreviations } \\ \text { S1P } & \text { sphingosine 1-phosphate } \\ \text { TNF } \alpha & \text { tumor necrosis factor alpha } \\ \text { S1PR } & \text { sphingosine 1-phosphate receptors } \\ \text { SK } & \text { sphingosine kinase } \\ \text { SPL } & \text { S1P lyase } \\ \text { SPP } & \text { S1P phosphatases } \\ \text { LPP } & \text { lipid phosphate phosphatases } \\ \text { Spns2 } & \text { spinster homolog } 2 \\ \text { NMR } & \text { Nuclear magnetic resonance } \\ \text { RMP } & \text { resting membrane potential } \\ \mathrm{R}_{m} & \text { membrane resistance } \\ \mathrm{C}_{\mathrm{m}} & \text { cell capacitance } \\ \text { PCA } & \text { principal component analysis }\end{array}$

\section{References}

1. Schiaffino, S.; Dyar, K.A.; Ciciliot, S.; Blaauw, B.; Sandri, M. Mechanisms Regulating Skeletal Muscle Growth and Atrophy. FEBS J. 2013, 280, 4294-4314. [CrossRef] [PubMed]

2. Hoshino, E.; Pichard, C.; Greenwood, C.E.; Kuo, G.C.; Cameron, R.G.; Kurian, R.; Kearns, J.P.; Allard, J.P.; Jeejeebhoy, K.N. Body Composition and Metabolic Rate in Rat during a Continuous Infusion of Cachectin. Am. J. Physiol. 1991, 260, E27-E36. [CrossRef]

3. Buck, M.; Chojkier, M. Muscle Wasting and Dedifferentiation Induced by Oxidative Stress in a Murine Model of Cachexia Is Prevented by Inhibitors of Nitric Oxide Synthesis and Antioxidants. EMBO J. 1996, 15, 1753-1765. [CrossRef] [PubMed]

4. Lang, C.H.; Frost, R.A.; Nairn, A.C.; MacLean, D.A.; Vary, T.C. TNF-Alpha Impairs Heart and Skeletal Muscle Protein Synthesis by Altering Translation Initiation. Am. J. Physiol. Endocrinol. Metab. 2002, 282, E336-E347. [CrossRef] [PubMed]

5. Llovera, M.; López-Soriano, F.J.; Argilés, J.M. Chronic Tumour Necrosis Factor-Alpha Treatment Modifies Protein Turnover in Rat Tissues. Biochem. Mol. Biol. Int. 1993, 30, 29-36.

6. Costelli, P.; Carbó, N.; Tessitore, L.; Bagby, G.J.; Lopez-Soriano, F.J.; Argilés, J.M.; Baccino, F.M. Tumor Necrosis Factor-Alpha Mediates Changes in Tissue Protein Turnover in a Rat Cancer Cachexia Model. J. Clin. Investig. 1993, 92, 2783-2789. [CrossRef] [PubMed]

7. Ahmad, S.; Karlstad, M.D.; Choudhry, M.A.; Sayeed, M.M. Sepsis-Induced Myofibrillar Protein Catabolism in Rat Skeletal Muscle. Life Sci. 1994, 55, 1383-1391. [CrossRef]

8. Li, Y.P.; Schwartz, R.J.; Waddell, I.D.; Holloway, B.R.; Reid, M.B. Skeletal Muscle Myocytes Undergo Protein Loss and Reactive Oxygen-Mediated NF-KappaB Activation in Response to Tumor Necrosis Factor Alpha. FASEB J. 1998, 12, 871-880. [CrossRef]

9. Li, Y.P.; Atkins, C.M.; Sweatt, J.D.; Reid, M.B. Mitochondria Mediate Tumor Necrosis Factor-Alpha/NF-KappaB Signaling in Skeletal Muscle Myotubes. Antioxid. Redox Signal. 1999, 1, 97-104. [CrossRef]

10. Tijerina, A.J. The Biochemical Basis of Metabolism in Cancer Cachexia. Dimens. Crit. Care Nurs. 2004, 23, 237-243. [CrossRef]

11. Tisdale, M.J. Metabolic Abnormalities in Cachexia and Anorexia. Nutrition 2000, 16, 1013-1014. [CrossRef]

12. Aggarwal, B.B. Signalling Pathways of the TNF Superfamily: A Double-Edged Sword. Nat. Rev. Immunol. 2003, 3, 745-756. [CrossRef] [PubMed] 
13. Clarke, C.J.; Truong, T.-G.; Hannun, Y.A. Role for Neutral Sphingomyelinase-2 in Tumor Necrosis Factor Alpha-Stimulated Expression of Vascular Cell Adhesion Molecule-1 (VCAM) and Intercellular Adhesion Molecule-1 (ICAM) in Lung Epithelial Cells: P38 MAPK Is an Upstream Regulator of NSMase2. J. Biol. Chem. 2007, 282, 1384-1396. [CrossRef] [PubMed]

14. Clarke, C.J.; Cloessner, E.A.; Roddy, P.L.; Hannun, Y.A. Neutral Sphingomyelinase 2 (NSMase2) Is the Primary Neutral Sphingomyelinase Isoform Activated by Tumour Necrosis Factor- $\alpha$ in MCF-7 Cells. Biochem. J. 2011, 435, 381-390. [CrossRef] [PubMed]

15. Hannun, Y.A.; Obeid, L.M. Sphingolipids and Their Metabolism in Physiology and Disease. Nat. Rev. Mol. Cell Biol. 2018, 19, 175-191. [CrossRef]

16. Cartier, A.; Hla, T. Sphingosine 1-Phosphate: Lipid Signaling in Pathology and Therapy. Science 2019, 366, eaar5551. [CrossRef]

17. Blaho, V.A.; Hla, T. An Update on the Biology of Sphingosine 1-Phosphate Receptors. J. Lipid Res. 2014, 55, 1596-1608. [CrossRef]

18. Spiegel, S.; Maczis, M.A.; Maceyka, M.; Milstien, S. New Insights into Functions of the Sphingosine-1-Phosphate Transporter SPNS2. J. Lipid Res. 2019, 60, 484-489. [CrossRef]

19. Kobayashi, N.; Kawasaki-Nishi, S.; Otsuka, M.; Hisano, Y.; Yamaguchi, A.; Nishi, T. MFSD2B Is a Sphingosine 1-Phosphate Transporter in Erythroid Cells. Sci. Rep. 2018, 8, 4969. [CrossRef]

20. Mitra, P.; Oskeritzian, C.; Spiegel, S. The Role of ABC Transporters in Sphingosine-1-Phosphate Secretion. FASEB J. 2007, 21 , A604. [CrossRef]

21. Donati, C.; Cencetti, F.; Bruni, P. Sphingosine 1-Phosphate Axis: A New Leader Actor in Skeletal Muscle Biology. Front. Physiol. 2013, 4, 338. [CrossRef] [PubMed]

22. Nagata, Y.; Partridge, T.A.; Matsuda, R.; Zammit, P.S. Entry of Muscle Satellite Cells into the Cell Cycle Requires Sphingolipid Signaling. J. Cell Biol. 2006, 174, 245-253. [CrossRef]

23. Nagata, Y.; Ohashi, K.; Wada, E.; Yuasa, Y.; Shiozuka, M.; Nonomura, Y.; Matsuda, R. Sphingosine-1-Phosphate Mediates Epidermal Growth Factor-Induced Muscle Satellite Cell Activation. Exp. Cell Res. 2014, 326, 112-124. [CrossRef] [PubMed]

24. Ieronimakis, N.; Pantoja, M.; Hays, A.L.; Dosey, T.L.; Qi, J.; Fischer, K.A.; Hoofnagle, A.N.; Sadilek, M.; Chamberlain, J.S.; Ruohola-Baker, H.; et al. Increased Sphingosine-1-Phosphate Improves Muscle Regeneration in Acutely Injured Mdx Mice. Skelet. Muscle 2013, 3, 20. [CrossRef] [PubMed]

25. Donati, C.; Meacci, E.; Nuti, F.; Becciolini, L.; Farnararo, M.; Bruni, P. Sphingosine 1-Phosphate Regulates Myogenic Differentiation: A Major Role for S1P2 Receptor. FASEB J. 2005, 19, 449-451. [CrossRef]

26. Becciolini, L.; Meacci, E.; Donati, C.; Cencetti, F.; Rapizzi, E.; Bruni, P. Sphingosine 1-Phosphate Inhibits Cell Migration in C2C12 Myoblasts. Biochim. Biophys. Acta 2006, 1761, 43-51. [CrossRef]

27. Nincheri, P.; Bernacchioni, C.; Cencetti, F.; Donati, C.; Bruni, P. Sphingosine Kinase-1/S1P1 Signalling Axis Negatively Regulates Mitogenic Response Elicited by PDGF in Mouse Myoblasts. Cell. Signal. 2010, 22, 1688-1699. [CrossRef]

28. Bernacchioni, C.; Cencetti, F.; Blescia, S.; Donati, C.; Bruni, P. Sphingosine Kinase/Sphingosine 1-Phosphate Axis: A New Player for Insulin-like Growth Factor-1-Induced Myoblast Differentiation. Skelet. Muscle 2012, 2, 15. [CrossRef]

29. Danieli-Betto, D.; Germinario, E.; Esposito, A.; Megighian, A.; Midrio, M.; Ravara, B.; Damiani, E.; Libera, L.D.; Sabbadini, R.A.; Betto, R. Sphingosine 1-Phosphate Protects Mouse Extensor Digitorum Longus Skeletal Muscle during Fatigue. Am. J. Physiol. Cell Physiol. 2005, 288, C1367-C1373. [CrossRef]

30. Zanin, M.; Germinario, E.; Dalla Libera, L.; Sandonà, D.; Sabbadini, R.A.; Betto, R.; Danieli-Betto, D. Trophic Action of Sphingosine 1-Phosphate in Denervated Rat Soleus Muscle. Am. J. Physiol. Cell Physiol. 2008, 294, C36-C46. [CrossRef]

31. Donati, C.; Nincheri, P.; Cencetti, F.; Rapizzi, E.; Farnararo, M.; Bruni, P. Tumor Necrosis Factor-Alpha Exerts pro-Myogenic Action in C2C12 Myoblasts via Sphingosine Kinase/S1P2 Signaling. FEBS Lett. 2007, 581, 4384-4388. [CrossRef] [PubMed]

32. Langen, R.C.J.; Van Der Velden, J.L.J.; Schols, A.M.W.J.; Kelders, M.C.J.M.; Wouters, E.F.M.; Janssen-Heininger, Y.M.W. Tumor Necrosis Factor-Alpha Inhibits Myogenic Differentiation through MyoD Protein Destabilization. FASEB J. 2004, 18, $227-237$. [CrossRef] [PubMed]

33. De Larichaudy, J.; Zufferli, A.; Serra, F.; Isidori, A.M.; Naro, F.; Dessalle, K.; Desgeorges, M.; Piraud, M.; Cheillan, D.; Vidal, H.; et al. TNF- $\alpha$ - and Tumor-Induced Skeletal Muscle Atrophy Involves Sphingolipid Metabolism. Skelet. Muscle 2012, 2, 2. [CrossRef] [PubMed]

34. Squecco, R.; Carraro, U.; Kern, H.; Pond, A.; Adami, N.; Biral, D.; Vindigni, V.; Boncompagni, S.; Pietrangelo, T.; Bosco, G.; et al. A Subpopulation of Rat Muscle Fibers Maintains an Assessable Excitation-Contraction Coupling Mechanism After Long-Standing Denervation Despite Lost Contractility. J. Neuropathol. Exp. Neurol. 2009, 68, 1256-1268. [CrossRef]

35. Pitson, S.M.; Xia, P.; Leclercq, T.M.; Moretti, P.A.B.; Zebol, J.R.; Lynn, H.E.; Wattenberg, B.W.; Vadas, M.A. PhosphorylationDependent Translocation of Sphingosine Kinase to the Plasma Membrane Drives Its Oncogenic Signalling. J. Exp. Med. 2005, 201, 49-54. [CrossRef] [PubMed]

36. Hait, N.C.; Bellamy, A.; Milstien, S.; Kordula, T.; Spiegel, S. Sphingosine Kinase Type 2 Activation by ERK-Mediated Phosphorylation. J. Biol. Chem. 2007, 282, 12058-12065. [CrossRef]

37. Bonaldo, P.; Sandri, M. Cellular and Molecular Mechanisms of Muscle Atrophy. Dis. Model. Mech. 2013, 6, 25-39. [CrossRef]

38. Bossola, M.; Muscaritoli, M.; Costelli, P.; Grieco, G.; Bonelli, G.; Pacelli, F.; Rossi Fanelli, F.; Doglietto, G.B.; Baccino, F.M. Increased Muscle Proteasome Activity Correlates with Disease Severity in Gastric Cancer Patients. Ann. Surg. 2003, 237, 384-389. [CrossRef]

39. Masiero, E.; Agatea, L.; Mammucari, C.; Blaauw, B.; Loro, E.; Komatsu, M.; Metzger, D.; Reggiani, C.; Schiaffino, S.; Sandri, M. Autophagy Is Required to Maintain Muscle Mass. Cell Metab. 2009, 10, 507-515. [CrossRef] 
40. Masiero, E.; Sandri, M. Autophagy Inhibition Induces Atrophy and Myopathy in Adult Skeletal Muscles. Autophagy 2010, 6, 307-309. [CrossRef]

41. Paolini, A.; Omairi, S.; Mitchell, R.; Vaughan, D.; Matsakas, A.; Vaiyapuri, S.; Ricketts, T.; Rubinsztein, D.C.; Patel, K. Attenuation of Autophagy Impacts on Muscle Fibre Development, Starvation Induced Stress and Fibre Regeneration Following Acute Injury. Sci. Rep. 2018, 8, 9062. [CrossRef] [PubMed]

42. Calise, S.; Blescia, S.; Cencetti, F.; Bernacchioni, C.; Donati, C.; Bruni, P. Sphingosine 1-Phosphate Stimulates Proliferation and Migration of Satellite Cells: Role of S1P Receptors. Biochim. Biophys. Acta 2012, 1823, 439-450. [CrossRef] [PubMed]

43. Jakubowski, A.A.; Casper, E.S.; Gabrilove, J.L.; Templeton, M.A.; Sherwin, S.A.; Oettgen, H.F. Phase I Trial of Intramuscularly Administered Tumor Necrosis Factor in Patients with Advanced Cancer. J. Clin. Oncol. 1989, 7, 298-303. [CrossRef] [PubMed]

44. Han, Y.; Weinman, S.; Boldogh, I.; Walker, R.K.; Brasier, A.R. Tumor Necrosis Factor-Alpha-Inducible IkappaBalpha Proteolysis Mediated by Cytosolic m-Calpain. A Mechanism Parallel to the Ubiquitin-Proteasome Pathway for Nuclear Factor-Kappab Activation. J. Biol. Chem. 1999, 274, 787-794. [CrossRef] [PubMed]

45. Takekura, H.; Fujinami, N.; Nishizawa, T.; Ogasawara, H.; Kasuga, N. Eccentric Exercise-Induced Morphological Changes in the Membrane Systems Involved in Excitation-Contraction Coupling in Rat Skeletal Muscle. J. Physiol. 2001, 533, 571-583. [CrossRef] [PubMed]

46. Favier, F.; Benoit, H.; Freyssenet, D. Cellular and Molecular Events Controlling Skeletal Muscle Mass in Response to Altered Use. Pflügers Arch. 2008, 456, 587-600. [CrossRef] [PubMed]

47. Waning, D.L.; Mohammad, K.S.; Reiken, S.; Xie, W.; Andersson, D.C.; John, S.; Chiechi, A.; Wright, L.E.; Umanskaya, A.; Niewolna, M.; et al. Excess TGF- $\beta$ Mediates Muscle Weakness Associated with Bone Metastases in Mice. Nat. Med. 2015, 21, 1262-1271. [CrossRef] [PubMed]

48. Zentella, A.; Manogue, K.; Cerami, A. Cachectin/TNF-Mediated Lactate Production in Cultured Myocytes Is Linked to Activation of a Futile Substrate Cycle. Cytokine 1993, 5, 436-447. [CrossRef]

49. Alvarez, B.; Quinn, L.S.; Busquets, S.; Quiles, M.T.; Lopez-Soriano, F.J.; Argiles, J.M. Tumor Necrosis Factor-Alpha Exerts Interleukin-6-Dependent and -Independent Effects on Cultured Skeletal Muscle Cells. Biochim. Biophys. Acta 2002, 1542, 66-72. [CrossRef]

50. Ninomiya, S.; Nakamura, N.; Nakamura, H.; Mizutani, T.; Kaneda, Y.; Yamaguchi, K.; Matsumoto, T.; Kitagawa, J.; Kanemura, N.; Shiraki, M.; et al. Low Levels of Serum Tryptophan Underlie Skeletal Muscle Atrophy. Nutrients 2020, 12, 978. [CrossRef]

51. Toyoshima, K.; Nakamura, M.; Adachi, Y.; Imaizumi, A.; Hakamada, T.; Abe, Y.; Kaneko, E.; Takahashi, S.; Shimokado, K. Increased Plasma Proline Concentrations Are Associated with Sarcopenia in the Elderly. PLoS ONE 2017, 12, e0185206. [CrossRef]

52. Patel, H.J.; Patel, B.M. TNF- $\alpha$ and Cancer Cachexia: Molecular Insights and Clinical Implications. Life Sci. 2017, 170, 56-63. [CrossRef]

53. Petersen, A.M.W.; Pedersen, B.K. The Anti-Inflammatory Effect of Exercise. J. Appl. Physiol. 2005, 98, 1154-1162. [CrossRef]

54. Li, Y.P.; Schwartz, R.J. TNF-Alpha Regulates Early Differentiation of C2C12 Myoblasts in an Autocrine Fashion. FASEB J. 2001, 15, 1413-1415. [CrossRef] [PubMed]

55. Xia, P.; Wang, L.; Gamble, J.R.; Vadas, M.A. Activation of Sphingosine Kinase by Tumor Necrosis Factor-Alpha Inhibits Apoptosis in Human Endothelial Cells. J. Biol. Chem. 1999, 274, 34499-34505. [CrossRef] [PubMed]

56. Radeff-Huang, J.; Seasholtz, T.M.; Chang, J.W.; Smith, J.M.; Walsh, C.T.; Brown, J.H. Tumor Necrosis Factor-Alpha-Stimulated Cell Proliferation Is Mediated through Sphingosine Kinase-Dependent Akt Activation and Cyclin D Expression. J. Biol. Chem. 2006, 282, 863-870. [CrossRef]

57. Pettus, B.J.; Bielawski, J.; Porcelli, A.M.; Reames, D.L.; Johnson, K.R.; Morrow, J.; Chalfant, C.E.; Obeid, L.M.; Hannun, Y.A. The Sphingosine Kinase 1/Sphingosine-1-Phosphate Pathway Mediates COX-2 Induction and PGE2 Production in Response to TNF-Alpha. FASEB J. 2003, 17, 1411-1421. [CrossRef] [PubMed]

58. Cencetti, F.; Bernacchioni, C.; Nincheri, P.; Donati, C.; Bruni, P. Transforming Growth Factor-Beta1 Induces Transdifferentiation of Myoblasts into Myofibroblasts via up-Regulation of Sphingosine Kinase-1/S1P3 Axis. Mol. Biol. Cell 2010, 21, 1111-1124. [CrossRef]

59. Meacci, E.; Nuti, F.; Donati, C.; Cencetti, F.; Farnararo, M.; Bruni, P. Sphingosine Kinase Activity Is Required for Myogenic Differentiation of C2C12 Myoblasts. J. Cell. Physiol. 2008, 214, 210-220. [CrossRef]

60. Pierucci, F.; Frati, A.; Battistini, C.; Matteini, F.; Iachini, M.C.; Vestri, A.; Penna, F.; Costelli, P.; Meacci, E. Involvement of Released Sphingosine 1-Phosphate/Sphingosine 1-Phosphate Receptor Axis in Skeletal Muscle Atrophy. Biochim. Biophys. Acta Mol. Basis Dis. 2018, 1864, 3598-3614. [CrossRef]

61. Pfitzenmaier, J.; Vessella, R.; Higano, C.S.; Noteboom, J.L.; Wallace, D.; Corey, E. Elevation of Cytokine Levels in Cachectic Patients with Prostate Carcinoma. Cancer 2003, 97, 1211-1216. [CrossRef] [PubMed]

62. Bernacchioni, C.; Ghini, V.; Cencetti, F.; Japtok, L.; Donati, C.; Bruni, P.; Turano, P. NMR Metabolomics Highlights Sphingosine Kinase-1 as a New Molecular Switch in the Orchestration of Aberrant Metabolic Phenotype in Cancer Cells. Mol. Oncol. 2017, 11, 517-533. [CrossRef] [PubMed]

63. Bernacchioni, C.; Cencetti, F.; Ouro, A.; Bruno, M.; Gomez-Muñoz, A.; Donati, C.; Bruni, P. Lysophosphatidic Acid Signaling Axis Mediates Ceramide 1-Phosphate-Induced Proliferation of C2C12 Myoblasts. Int. J. Mol. Sci. 2018, 19, 139. [CrossRef] [PubMed] 
64. Bruno, G.; Cencetti, F.; Bernacchioni, C.; Donati, C.; Blankenbach, K.V.; Thomas, D.; Meyer zu Heringdorf, D.; Bruni, P. Bradykinin Mediates Myogenic Differentiation in Murine Myoblasts through the Involvement of SK1/Spns2/S1P 2 Axis. Cell. Signal. 2018, 45, 110-121. [CrossRef]

65. Cencetti, F.; Bernacchioni, C.; Bruno, M.; Squecco, R.; Idrizaj, E.; Berbeglia, M.; Bruni, P.; Donati, C. Sphingosine 1-PhosphateMediated Activation of Ezrin-Radixin-Moesin Proteins Contributes to Cytoskeletal Remodeling and Changes of Membrane Properties in Epithelial Otic Vesicle Progenitors. Biochim. Biophys. Acta Mol. Cell Res. 2019, 1866, 554-565. [CrossRef]

66. Livak, K.J.; Schmittgen, T.D. Analysis of Relative Gene Expression Data Using Real-Time Quantitative PCR and the 2(-Delta Delta C(T)) Method. Methods 2001, 25, 402-408. [CrossRef]

67. Vignoli, A.; Ghini, V.; Meoni, G.; Licari, C.; Takis, P.G.; Tenori, L.; Turano, P.; Luchinat, C. High-Throughput Metabolomics by 1D NMR. Angew. Chem. Int. Ed. Engl. 2019, 58, 968-994. [CrossRef]

68. Takis, P.G.; Ghini, V.; Tenori, L.; Turano, P.; Luchinat, C. Uniqueness of the NMR Approach to Metabolomics. TrAC Trends Anal. Chem. 2018, 120, 115300. [CrossRef]

69. Ghini, V.; Quaglio, D.; Luchinat, C.; Turano, P. NMR for Sample Quality Assessment in Metabolomics. New Biotechnol. 2019, 52, 25-34. [CrossRef]

70. D'Alessandro, G.; Quaglio, D.; Monaco, L.; Lauro, C.; Ghirga, F.; Ingallina, C.; De Martino, M.; Fucile, S.; Porzia, A.; Di Castro, M.A.; et al. 1H-NMR Metabolomics Reveals the Glabrescione B Exacerbation of Glycolytic Metabolism beside the Cell Growth Inhibitory Effect in Glioma. Cell Commun. Signal. 2019, 17, 108. [CrossRef]

71. Perrin, E.; Ghini, V.; Giovannini, M.; Di Patti, F.; Cardazzo, B.; Carraro, L.; Fagorzi, C.; Turano, P.; Fani, R.; Fondi, M. Diauxie and Co-Utilization of Carbon Sources Can Coexist during Bacterial Growth in Nutritionally Complex Environments. Nat. Commun. 2020, 11, 3135. [CrossRef] [PubMed]

72. Squecco, R.; Chellini, F.; Idrizaj, E.; Tani, A.; Garella, R.; Pancani, S.; Pavan, P.; Bambi, F.; Zecchi-Orlandini, S.; Sassoli, C. PlateletRich Plasma Modulates Gap Junction Functionality and Connexin 43 and 26 Expression During TGF-B1-Induced Fibroblast to Myofibroblast Transition: Clues for Counteracting Fibrosis. Cells 2020, 9, 1199. [CrossRef] [PubMed]

73. Collins, C.A.; Rojas, E.; Suarez-Isla, B.A. Fast Charge Movements in Skeletal Muscle Fibres from Rana Temporaria. J. Physiol. 1982, 324, 319-345. [CrossRef] [PubMed]

74. Squecco, R.; Idrizaj, E.; Morelli, A.; Gallina, P.; Vannelli, G.B.; Francini, F. An Electrophysiological Study on the Effects of BDNF and FGF2 on Voltage Dependent $\left.\mathrm{Ca}^{2+}{ }^{+}\right)$Currents in Developing Human Striatal Primordium. Mol. Cell. Neurosci. 2016, 75, 50-62. [CrossRef] 